\title{
Cell division in Corynebacterineae
}

\section{Catriona Donovan * and Marc Bramkamp *}

Department of Biology I, Ludwig-Maximilians-University, Munich, Planegg-Martinsried, Germany

\section{Edited by:}

Wendy Schluchter, University of

New Orleans, USA

Reviewed by:

Julia Frunzke, Jülich Research

Centre, Germany

Andreas Burkovski, Friedric

University of Erlangen-Nuremberg

(FAU), Germany

\section{*Correspondence:}

Catriona Donovan and Marc

Bramkamp, Department of Biology I,

Ludwig-Maximilians-University,

Munich, Großhaderner Str. 2-4,

82152 Planegg-Martinsried,

Germany

e-mail:c.donovan@

biologie.uni-muenchen.de

marc.bramkamp@Imu.de
Bacterial cells must coordinate a number of events during the cell cycle. Spatio-temporal regulation of bacterial cytokinesis is indispensable for the production of viable, genetically identical offspring. In many rod-shaped bacteria, precise midcell assembly of the division machinery relies on inhibitory systems such as Min and Noc. In rod-shaped Actinobacteria, for example Corynebacterium glutamicum and Mycobacterium tuberculosis, the divisome assembles in the proximity of the midcell region, however more spatial flexibility is observed compared to Escherichia coli and Bacillus subtilis. Actinobacteria represent a group of bacteria that spatially regulate cytokinesis in the absence of recognizable Min and Noc homologs. The key cell division steps in E. coli and B. subtilis have been subject to intensive study and are well-understood. In comparison, only a minimal set of positive and negative regulators of cytokinesis are known in Actinobacteria. Nonetheless, the timing of cytokinesis and the placement of the division septum is coordinated with growth as well as initiation of chromosome replication and segregation. We summarize here the current knowledge on cytokinesis and division site selection in the Actinobacteria suborder Corynebacterineae.

Keywords: cell division, cell cycle, Par system, Corynebacterium glutamicum, Mycobacterium tuberculosis, FtsZ, DivIVA, serine/threonine kinases

\section{INTRODUCTION}

Bacterial reproduction by binary fission follows an ordered, programmed sequence of events in which cells increase in mass, replicate genetic material, and segregate newly formed chromosomes before dividing the cytoplasmic and genetic material into two daughter cells. The production of viable progeny necessitates that chromosome replication is initiated at a given cell mass, that the assembly of the cell division machinery is regulated such that it does not precede replication initiation or segregation and, as the divisome matures and as the chromosomes segregate, that membrane invagination is coordinated with cell wall synthesis between the segregated chromosomes. The stages involved in the bacterial cell cycle are not discrete, but rather overlapping and thus often presenting challenges during rapid growth. Chromosome replication initiates at the origin of replication $($ oriC) and is replicated bi-directionally until the replication machineries meet at the terminus region $(\operatorname{ter} C)$. Initiation of chromosome replication is regulated so that the overall rate of DNA synthesis is controlled and is coordinated with cell growth, chromosome segregation as well as cell division (for reviews see Reyes-Lamothe et al., 2012; Costa et al., 2013). Under nutrient rich conditions where cells are growing rapidly, Bacillus subtilis and Escherichia coli initiate new rounds of replication prior to completion of the previous round, a phenomenon termed multifork replication. However, multifork replication is not ubiquitous. Caulobacter crescentus, for example, initiates replication only once per cell cycle. The situation in other bacteria, such as Corynebacterium glutamicum, is less clear. Using a marker for the oriC, up to four oriC foci have been observed in dividing C. glutamicum cells, suggesting that multifork replication may not occur (Donovan et al., 2010). However, using flow cytometry up to 16 chromosomes per cell has been recently reported for C. glutamicum grown in complex medium (Neumeyer et al., 2013).

A fundamental step in the cycle is the spatial and temporal regulation of cytokinesis, best understood in B. subtilis and E. coli. These rod shaped bacteria divide with extraordinary accuracy precisely at the midcell. However, this accuracy in division site placement does not hold true for all rod shaped bacteria. Members of the Actinobacteria phylum are GCrich gram positive bacteria, encompassing one of the largest phyla within Bacteria. The morphologies of this phylum are diverse, ranging from coccoid (Rhodococcus, Micrococcus), to rod (Corynebacterium, Mycobacterium) to even fungal-like hyphae with branched mycelium (Streptomyces, Nocardia). Actinobacteria comprise a number of human pathogens (Mycobacterium tuberculosis, Mycobacterium leprae, and Corynebacterium diphtheriae) as well as non-pathogenic members (C. glutamicum, Streptomyces coelicolor). The cell wall structure of Corynebacterineae, the suborder which is the focus of this review, is highly unusual. In addition to a peptidoglycan layer Corynebacteria and Mycobacteria contain an outer membrane composed of mycolic acids that is covalently linked to peptidoglycan via the polysaccharide arabinogalactan network (for review see Hett and Rubin, 2008; Favrot and Ronning, 2012). This cell wall structure greatly contributes to resistance to antimicrobial compounds as well as various stress conditions. Aside from the medical importance of Actinobacteria as human pathogens, some members such as C. glutamicum and Streptomyces are industrially central in the production of amino acids and antibiotics, respectively. Regarding biotechnological applications, these organisms have been intensively studied and are now established model organisms (Wieschalka et al., 2013). Nonetheless, relatively little is known about the cell biology of these bacteria. 
From initial observations it was clear that Actinobacteria differ from the conventional cell biology model organisms such as $B$. subtilis and E. coli. Genome sequencing revealed that some Actinobacteria lack an actin homolog. Streptomyces encode actin homologs that are dispensable for growth (Burger et al., 2000) but are required during exo-spore formation (Mazza et al., 2006). The actin homolog MreB (and its paralogs) plays a critical role in cell elongation in B. subtilis and E. coli, which in many rod shaped bacteria occurs by intercalation of new peptidoglycan into the cell wall along most of its length (for review see Chastanet and Carballido-Lopez, 2012). Cell division gives rise to hemispherical cell poles in $E$. coli, which are largely inert after formation (De Pedro et al., 2001). In the case of Actinobacteria, intercalation of new cell wall material occurs at the cell poles, giving rise to an apical mode of cell elongation (Gray et al., 1990; Daniel and Errington, 2003; Letek et al., 2008b). After maturation of the divisome and completion of cytokinesis, the elongasome (cell wall synthesis machinery) is assembled at the young cell pole and elongation occurs at both poles (Daniel and Errington, 2003). The precise assembly of the elongasome is not completely understood, nor is the existence of two distinct cell division and elongation machineries. In C. glutamicum and M. tuberculosis/smegmatis as well as other members of the Actinobacteria phylum, DivIVA (Wag31 in Mycobacteriaceae), has been implicated as an organizer of apical growth (for review see Nguyen et al., 2007; Letek et al., 2008b; Flärdh, 2010).

Compared to established cell division model organisms, striking differences are found in the process of division site selection and cytokinesis in Actinobacteria. The incredible precision in division site selection observed for B. subtilis and E. coli contrasts to C. glutamicum and M. tuberculosis. It is, therefore, not entirely surprising that the regulatory mechanisms employed by $B$. subtilis and E. coli are lacking in Actinobacteria. Nonetheless, the genetic integrity of Actinobacteria offspring is faithfully maintained.

This review will focus on the current knowledge of cell division in Corynebacterineae, with particular emphasis on C. glutamicum and $M$. tuberculosis/M. smegmatis, and, where appropriate, draw comparisons with other well-established model organisms such as B. subtilis, E. coli and C. crescentus.

\section{BACTERIAL CYTOKINESIS}

The bacterial cytokinetic machinery, also known as the divisome, is composed of a large number of diverse proteins, many of which are essential for the formation of a functional division apparatus (Table 1) (for review see Adams and Errington, 2009; Lutkenhaus et al., 2012). In B. subtilis and E. coli, divisome assembly requires the cooperative recruitment of cell division proteins. Assembly of the divisome is initiated by the highly conserved tubulin homolog FtsZ (Bi and Lutkenhaus, 1991). Polymerization of FtsZ into a ring like structure, termed the Z-ring, at the nascent division site forms the cytoskeletal scaffold to which other cell division proteins are recruited. A two stage assembly process for Z-ring formation has been proposed; (i) polymerization of FtsZ into single stranded protofilaments and (ii) lateral interaction between the protofilaments forming stable bundles (Romberg and Levin, 2003). FtsZ rings are dynamic, exhibiting constant subunit exchange with cytosolic molecules (Anderson et al., 2004). Therefore, in order for cell division to occur, the Zring must be stabilized at the right time and place during the cell cycle. Both positive and negative regulatory proteins are involved in this process.

\section{DIVISOME COMPONENTS AND ASSEMBLY}

In B. subtilis and E. coli, FtsZ levels do not fluctuate during the cell cycle, thus Z-ring assembly must be subject to regulation (Weart and Levin, 2003), contrary to the situation in C. crescentus (Hottes et al., 2005). The cellular signals required for Z-ring assembly are not completely understood, however a slight increase in FtsZ level results in multiple, non-productive Z-rings, while fts $Z$ overexpression leads to filamentous cells, suggesting that the assembly of FtsZ ring formation is controlled by both positive and negative factors. The impact of altering FtsZ levels is more severe in C. glutamicum and M. tuberculosis, suggesting that cell division in these organisms is sensitive to the intracellular levels of FtsZ (Dziadek et al., 2003; Ramos et al., 2005; Letek et al., 2007). Overexpression of $f t s Z$ in C. glutamicum gives rise to altered morphology as well as altered nucleoid localization (Letek et al., 2007).

Assembly of the divisome is a two-step process with a time delay of approximately $20 \%$ of the cell cycle between the two steps. After recruitment of FtsZ to the nascent division site, a group of early recruited proteins facilitate anchoring of Fts $Z$ to the membrane and stabilization of the Z-ring (in E. coli-FtsA, ZipA, ZapA, FtsK and in B. subtilis-FtsA, ZapA, EzrA, SepF, ClpX) (for review see Huang et al., 2013). The late recruited divisome components are mostly membrane anchored proteins involved in the maturation of the divisome and recruitment appears to follow a hierarchical interdependent pattern (in E. coli-FtsB, FtsQ, FtsL, FtsW, FtsI, FtsN and in B. subtilis-DivIB, DivIC, FtsL, Pbp2b, FtsW, SpoIIIE) (for review see Margolin, 2005; Lutkenhaus et al., 2012). In the final steps, septal peptidoglycan synthesis and constriction of the cell envelope are triggered, before murein hydrolases separate the daughter cells.

\section{MEMBRANE TETHERING AND STABILIZATION OF THE Z-RING}

Given that FtsZ itself does not have affinity for the membrane, additional factors to stably tether the Z-ring to the cell membrane are required. In E. coli, the actin homolog FtsA targets FtsZ to the membrane via an amphipathic helix (Pichoff and Lutkenhaus, 2005). In B. subtilis ftsA mutants are extremely filamentous (Beall and Lutkenhaus, 1992). In the absence of FtsA, ZipA is essential to tether Z-rings to the E. coli membrane (Hale and De Boer, 1997). Recent evidence suggests that FtsA is the dominant Zring tethering factor and ZipA may function in the disruption of FtsA self-interaction allowing FtsA to interact with and tether FtsZ rings to the membrane (Pichoff et al., 2012). Similar to other early recruited divisome components, FtsA is required for the recruitment of downstream cell division proteins. In E. coli, two cytoplasmic components of the division machinery, ZipA and ZapA, have been reported to promote lateral bundling of the GTP bound FtsZ protofilaments, stabilizing the Z-rings (Hale and De Boer, 1997; Liu et al., 1999; Raychaudhuri, 1999; Gueiros-Filho and Losick, 2002). In vitro evidence has recently been presented proposing that ZipA restructures FtsZ polymers leading to the formation of higher ordered structures (Mateos-Gil et al., 2012). 
Table 1 | Putative cell division gene of C. glutamicum (Cgb), M. tuberculosis (Mtu) or M. smegmatis (Msm), E. coli (Eco), and B. subtilis (Bsu).

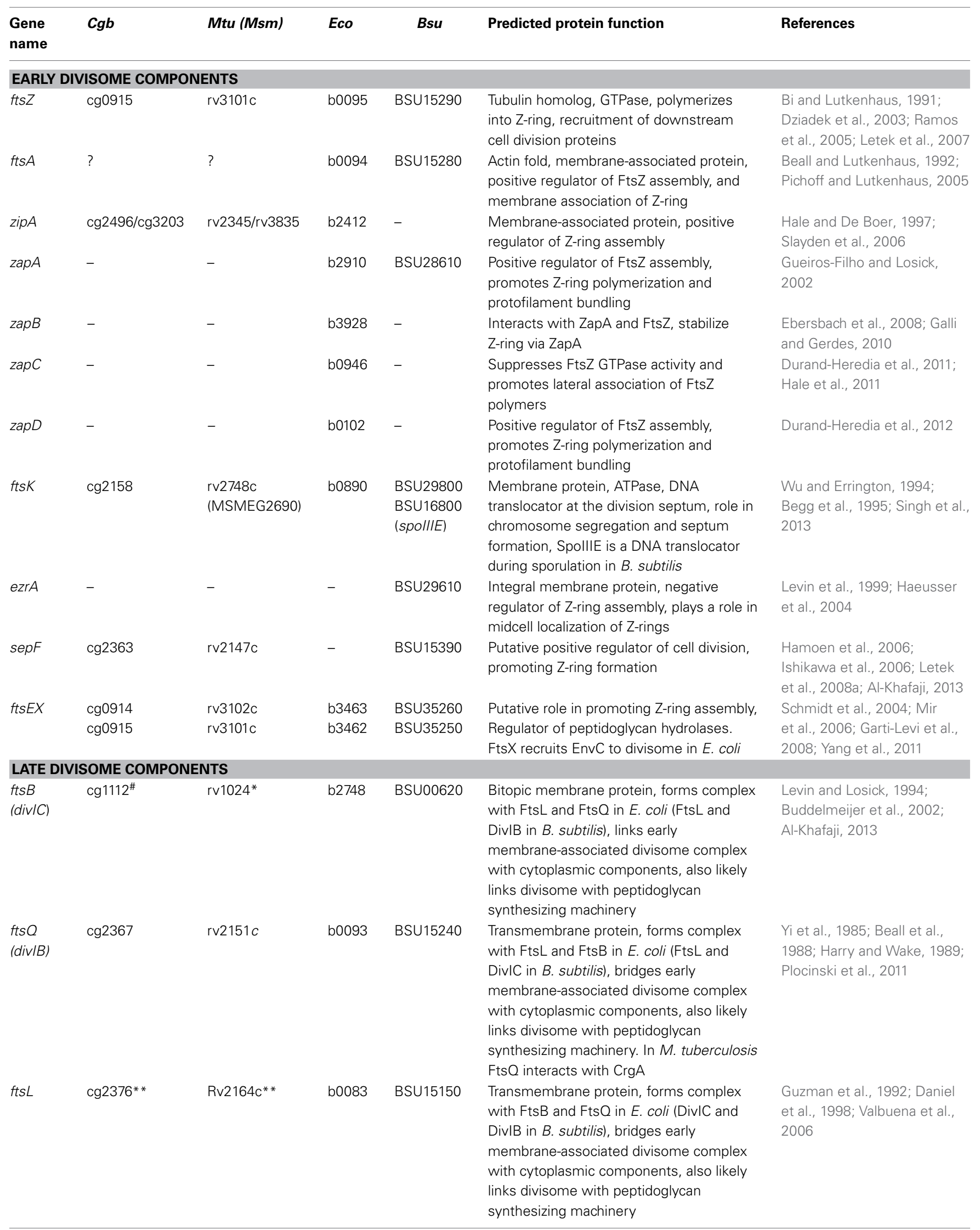


Table 1 | Continued

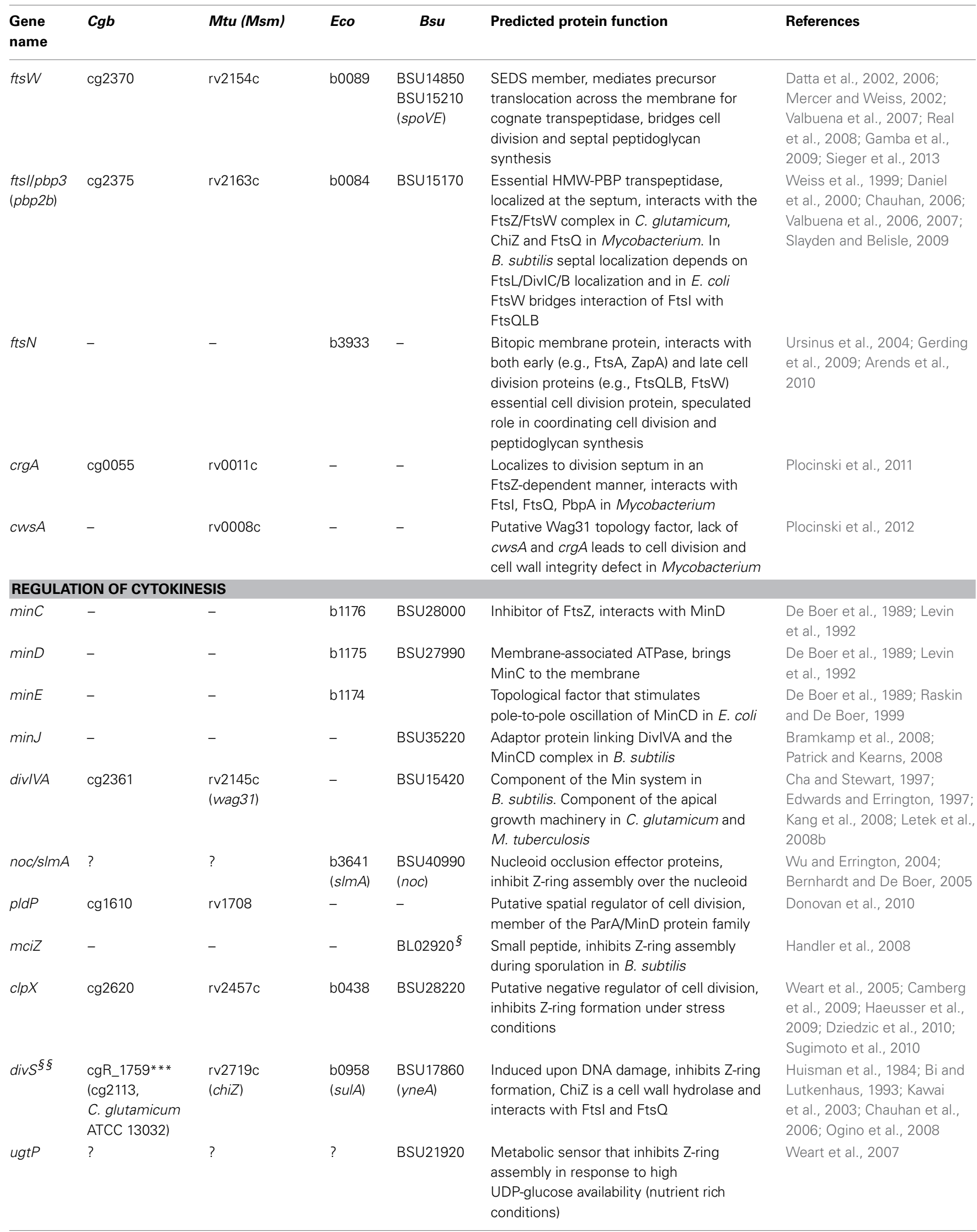


Table 1 | Continued

\begin{tabular}{|c|c|c|c|c|c|c|}
\hline $\begin{array}{l}\text { Gene } \\
\text { name }\end{array}$ & $C g b$ & Mtu (Msm) & Eco & Bsu & Predicted protein function & References \\
\hline \multicolumn{7}{|c|}{ CELL SEPARATION } \\
\hline envC & $\begin{array}{l}\text { cgR_1596*** } \\
\text { (cg1735, } \\
\text { C. glutamicum } \\
\text { ATCC 13032) }\end{array}$ & $\begin{array}{l}\text { rv1477 } \\
\text { (ripA) }\end{array}$ & b3613 & $\begin{array}{l}\text { BSU34800 } \\
(\mathrm{cw} / O)\end{array}$ & $\begin{array}{l}\text { LytM domain containing, activator of } \\
\text { amidases AmiC (and AmiB) (E. coli), } \\
\text { regulated by FtsEX. RipA interacts with } \\
\text { the lytic transglycosylase Rpf, depletion of } \\
\text { ripA leads to chains of cells }\end{array}$ & $\begin{array}{l}\text { Bernhardt and De Boer, 2004; } \\
\text { Hett et al., 2008; Tsuge et al., } \\
\text { 2008; Yang et al., 2011; } \\
\text { Meisner et al., } 2013\end{array}$ \\
\hline
\end{tabular}

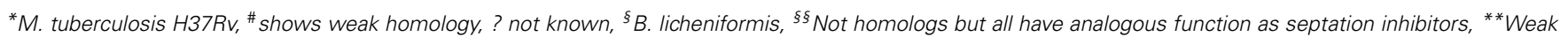
homology but similar topology, ${ }^{* *} \mathrm{C}$. glutamicum $R$.

Although not essential under normal lab growth conditions, $B$. subtilis cells lacking $z a p A$ are found to be synthetic lethal in the absence of ezrA (see below) or in cells with reduced FtsZ levels (Gueiros-Filho and Losick, 2002).

Genome wide blasts to identify conventional FtsZ interacting proteins revealed that C. glutamicum, as well as other members of the Actinobacteria phylum, lack the eminent positive regulators (FtsA, ZipA, or ZapA) found in the conventional rod-shaped bacteria (Letek et al., 2007; Hett and Rubin, 2008). However, transcription profiling of $M$. tuberculosis cells inhibited for septum formation revealed two potential orthologs of ZipA (Rv2345 and Rv3835) (Slayden et al., 2006). Homologs of the putative M. tuberculosis cell division proteins can also be found in C. glutamicum (Cg2496 and Cg3203, respectively), however an involvement in cell division remains to be validated in both organisms.

Another FtsZ interacting partner is SepF, a positive regulator of cell division in B. subtilis (Hamoen et al., 2006). SepF associates with the membrane through an $\mathrm{N}$-terminal amphipathic helix and recruits FtsZ by binding to the C-terminal domain of FtsZ (Król et al., 2012; Duman et al., 2013). Mutants of sepF are viable, however cells have a mild division defect (Hamoen et al., 2006; Król et al., 2012). SepF is widely conserved in gram positive bacteria, with homologs in both C. glutamicum (Cg2363) and M. tuberculosis (Rv2147c) (Letek et al., 2007). A more detailed study is required before these homologs can be assigned a specific function or role in the C. glutamicum divisome complex.

The FtsEX complex, which structurally resembles an $\mathrm{ABC}$ transporter, is recruited relatively early to the divisome (Schmidt et al., 2004). FtsE encompasses the ATPase domain while FtsX forms the transmembrane domain of the complex (Arends et al., 2009). In E. coli, FtsEX is essential only under low osmolarity conditions, where it functions to regulate peptidoglycan hydrolases (Schmidt et al., 2004). Midcell localization of FtsX is achieved through interactions with FtsA and FtsQ, while FtsE interacts directly with FtsZ in E. coli (Schmidt et al., 2004; Corbin et al., 2007). In B. subtilis, FtsEX is found all around the cell membrane and plays a role in the spatio-temporal regulation of sporulation, although the precise mechanism is not known, yet (GartiLevi et al., 2008). It has recently been proposed that FtsEX of Streptococcus pneumoniae and B. subtilis functions in signal transduction coupling peptidoglycan hydrolysis and cell division (Meisner et al., 2013; Sham et al., 2013). More recently, FtsEX was shown to regulate the activity of CwlO (a cell wall hydrolytic enzyme) (Dominguez-Cuevas et al., 2013; Meisner et al., 2013). FtsEX of C. crescentus is recruited to the nascent division site prior to FtsA, and hence is speculated to play a role in tethering of Z-rings to the membrane (Goley et al., 2011). The genomes of C. glutamicum and M. tuberculosis contain FtsEX homologs, however relatively little is known about their function in the respective organisms, not to mention a potential role in cell division. In M. tuberculosis, FtsEX exists as a complex found in the membrane (Mir et al., 2006), however the precise subcellular localization is not known, yet. It is tempting to speculate that in bacteria lacking FtsA, FtsEX plays a role in promoting FtsZ assembly and stability at the impending division site.

\section{NEGATIVE REGULATION OF DIVISOME ASSEMBLY}

In pre-divisional B. subtilis cells, EzrA is found throughout the membrane and has been proposed to prevent FtsZ assembly at inappropriate sites other than mid-cell, impacting on spatial regulation of the Z-rings. At the onset of Z-ring assembly EzrA becomes concentrated at the nascent division site where it is speculated to interact directly with FtsZ playing a role in remodeling of the division rings (Levin et al., 1999; Haeusser et al., 2004). In cells lacking ezrA, extra Z-rings can form because the critical EzrA concentration required for Fts $Z$ assembly is reduced. Thus, EzrA ensures that Z-rings form only once per cycle, or it might prevent Z-ring assembly at the cell poles (Levin et al., 1999). In Staphylococcus aureus, EzrA appears to be important for maintaining correct cell size (Jorge et al., 2011). Additionally, these cells lacking ezrA have delocalized FtsZ and PBP's, along with septa aberrations (Jorge et al., 2011). EzrA homologs have not been 
identified in C. glutamicum or M. tuberculosis, however as outlined below there are a number of proteins that might function analogous to EzrA.

The highly conserved ClpX protein has been shown to play a role in modulating cell division in a number of bacteria. In B. subtilis, the ClpX chaperone (the substrate recognition domain of the ClpXP protease) inhibits Z-ring formation in an ATP hydrolysis independent manner (Weart et al., 2005). It was proposed that ClpX sterically interferes with FtsZ assembly (Weart et al., 2005; Haeusser et al., 2009). The ClpXP protease has been implicated in regulating cell division in a number of organisms. In C. crescentus, this complex degrades the master regulator, CtrA, and thereby modulates the expression of cell division genes, including $f t s Z$, in a cell cycle dependent manner. In E. coli, ClpXP has been proposed to modulate FtsZ polymer dynamics, either through degradation of the FtsZ monomers and polymers (Camberg et al., 2009) or by disassembling FtsZ polymers (Sugimoto et al., 2010). In M. tuberculosis, ClpX (Rv2457c) has been reported to interact with FtsZ independent of the oligomeric state of FtsZ or its association with other proteins (Dziedzic et al., 2010). In vivo, ClpX and FtsZ colocalize, however this colocalization was more prominent with polar FtsZ foci (Dziedzic et al., 2010). ClpX is upregulated under stress conditions, such as exposure to antibiotics or intracellular growth of M. tuberculosis and has been proposed to bind FtsZ monomers inhibiting assembly of a functional Z-ring, delaying cell division under stress conditions. Alternatively, polar localized ClpX could function to prevent reassembly of a polar Z-ring (Dziedzic et al., 2010). In M. tuberculosis, it is not clear if ClpX is essential under normal growth conditions. Reduced levels of the essential ClpX protein appears to alter FtsZ ring formation, however this could be an indirect effect (Dziedzic et al., 2010). A homolog of ClpX is present in the C. glutamicum genome (cg2620) (Table 1).

DNA damage leads to inhibition of Z-ring formation allowing cells to repair damaged DNA without guillotining the chromosome or produce offspring with damaged genomes. The SOS response induced under such conditions is controlled by RecA and LexA proteins. Upon DNA damage, RecA is activated and inhibits the DNA-binding capacity of LexA by proteolytic cleavage LexA is a suppressor of SOS response genes under normal growth conditions (Little et al., 1980; Horii et al., 1981). In C. glutamicum, the expression of up to 48 genes is controlled by LexA, many of unknown function (Jochmann et al., 2009). In C. glutamicum R, an unrelated protein DivS (CgR_1759, C. glutamicum ATCC13032 Cg2113) is induced in response to DNA damage (Ogino et al., 2008). Induction of DNA damage and expression of $\operatorname{divS}$ by mitomycin $\mathrm{C}$ treatment or overexpression of divS suppresses cell division by reduced Z-ring formation (Ogino et al., 2008). The morphological defects of a $\operatorname{divS}$ overexpression mutant, elongated cells with growth from ectopic sites (Ogino et al., 2008), are similar to mutants with reduced FtsZ levels (Ramos et al., 2005). These morphological defects could not be complemented by overexpression of $f t s Z$, suggesting that suppression of cell division does not involve a direct interaction with FtsZ.

In Mycobacterium, the cell wall hydrolase ChiZ (Rv2719c) is induced upon DNA damage and acts as a negative regulator of cell division (Chauhan, 2006). When overexpressed fewer FtsZ rings per cell were observed. In the absence of chiZ, FtsZ rings were stabilized. An interaction of ChiZ with FtsI and FtsQ was observed, but not with FtsZ or Wag31 (DivIVA in C. glutamicum). ChiZ does not influence the localization of FtsI, FtsQ, or Wag31, suggesting that recruitment and function of ChiZ is downstream of FtsI/Q assembly to the divisome. ChiZ has an extracellular LysM domain, however this does not appear to be necessary for its function (Chauhan, 2006).

In E. coli, the SulA is induced in the SOS response (Huisman et al., 1984; Bi and Lutkenhaus, 1993) and inhibits cell division by binding directly to FtsZ and inhibiting its polymerization (Mukherjee et al., 1998). In B. subtilis, YneA, a transmembrane protein with an extracellular LysM peptidoglycan binding domain, is induced upon DNA damage (Kawai and Ogasawara, 2006). YneA does not interact directly with FtsZ and during the SOS response Z-ring formation is reduced as opposed to complete abolishment. The C. glutamicum DivS does not share significant homology to YneA; however the genomic organization is similar, with the lexA gene found in close proximity to SOS-induced genes.

\section{COORDINATION OF CELL DIVISION WITH SEPTAL PEPTIDOGLYCAN SYNTHESIS}

The recruitment and stabilization of the Z-ring at the nascent division site must be followed by divisome constriction, meaning septal peptidoglycan synthesis must be initiated so that invagination of the cell envelope leads to synthesis of new cell poles and separation of the daughter cells. The precursor molecules required for peptidoglycan synthesis must be translocated across the membrane by the action of lipid II flipases before incorporation into the inner membrane by the action of penicillin-binding proteins $(\mathrm{Pbp})$. The relatively late recruited divisome protein FtsW is a member of the SEDS (shape, elongation, division, and sporulation) protein family that mediates precursor translocation across the membrane (Ehlert and Höltje, 1996; Mohammadi et al., 2011). FtsW is normally found associated with its cognate Pbp. The E. coli FtsW localizes Pbp3 (FtsI) to the divisome, while divisome recruitment of FtsW is dependent on FtsL and FtsQ (Mercer and Weiss, 2002). In M. tuberculosis, FtsW is a central component in a complex that bridges cell division and septal peptidoglycan synthesis (Datta et al., 2002, 2006). Four aspartic acids at the carboxyl terminus of FtsZ are required for FtsW interaction, while the C-terminal region of Pbp3 (FtsI) appears to be necessary for interaction with FtsW (Datta et al., 2002, 2006). Given that an FtsZ variant in which the three aspartic acids of the C-terminus of FtsZ were mutated to alanine could not be expressed as the only copy, it has been proposed that this region of FtsZ is essential for FtsZ activity and cell division in M. tuberculosis (Rajagopalan et al., 2005). When expressed in trans, the FtsZ mutant variant associated with the Z-ring indicating that self-interaction was not impaired. Conditional inactivation of M. smegmatis FtsW did not impede targeting of FtsZ to the nascent division site, however Pbp3 (FtsI) fails to localize (Datta et al., 2006). Septation was compromised in cells with reduced FtsW levels in addition to longer cells, with multiple, probably non-functional, Z-rings positioned between segregated chromosomes. 
In C. glutamicum, FtsW localizes to the division septa (Sieger et al., 2013) where it interacts with FtsZ directly (Valbuena et al., 2007). However, the temporal order of FtsW recruitment to the divisome is not yet known. Similar to FtsW, FtsI is essential in C. glutamicum and localizes to the division septum likely in an FtsW-dependent manner, similar to E. coli and B. subtilis (Weiss et al., 1999; Daniel et al., 2000; Valbuena et al., 2006, 2007). Reduced expression of ftsI causes severe morphological defects and also induces the expression of several genes, including divIVA, which is involved in apical growth (Valbuena et al., 2006).

\section{CELL DIVISION PROTEINS SPECIFIC TO ACTINOBACTERIA}

Originally identified and characterized in S. coelicolor, CrgA is a protein that has been implicated in cell division in Actinobacteria. In M. tuberculosis, altered expression of $\operatorname{crgA}$ led to cell morphological as well as division defects, but did not affect FtsZ levels (Plocinski et al., 2011). Localization studies of the M. tuberculosis CrgA in M. smegmatis revealed that CrgA localizes to the division septum in an FtsZ-dependent manner but does not influence Z-ring localization (Plocinski et al., 2011). Interaction with FtsZ could be mapped to the N-terminal domain of CrgA. Further interaction analysis revealed that CrgA interacts with FtsI, FtsQ, and $\mathrm{PbpA}$, and is required for FtsI septal localization. CrgA might be required for the recruitment of components of the peptidoglycan synthesis machinery, such as FtsI and PbpA (transpeptidases involved in peptidoglycan cross-linking during septum synthesis), to the mature division site as synthesis of the invagination septum begins to occur. C. glutamicum also encodes a CrgA homolog (Cg0055), however this protein has not been investigated to date.

Further evidence that CrgA synchronizes cell division and cell septation came from interactions with a novel mycobacterial protein, CwsA. This small transmembrane protein localizes to the cell poles and division septum. Single deletion of $c w s A$ did not influence Z-ring localization, however combined deletion of $c w s A$ and $\operatorname{crg} A$ did compromise Z-ring assembly and cell wall integrity (Plocinski et al., 2012). In addition, deletion of $c w s A$ negatively influenced cell growth and morphology, but more interestingly has been reported to alter the localization of Wag31 (DivIVA in C. glutamicum) (Plocinski et al., 2012), the orchestrator of apical growth in Actinobacteria. So far, the only evidence that CwsA and Wag31 interact came from a bacterial two hybrid analysis (Plocinski et al., 2012).

Positive regulators of Fts $\mathrm{Z}$ polymerization have also been described for Streptomyces coelicolor. During vegetative growth FtsZ is dispensable but spore development defects are observed (McCormick et al., 1994; McCormick and Losick, 1996). Two novel positive regulators of FtsZ, SsgA, and SsgB, were identified recently in S. coelicolor (Willemse et al., 2011). SsgA and SsgB localize independently of FtsZ (Willemse et al., 2011), however in their absence sporulation is blocked (Van Wezel et al., 2000; Keijser et al., 2003). In young aerial hyphae, SsgA localizes to alternating sides of the aerial hyphae membrane, recruiting SsgB to these sites. SsgB is speculated to tether the FtsZ spiraling filaments to the membrane of sporulating cells.

\section{DIVISION SITE SELECTION}

Essentially, FtsZ lays the foundation for the subcellular localization and symmetry of the division site. Aside from protein-protein interactions that stabilize Z-ring formation and assembly of the cytokinetic machinery, FtsZ is also subject to spatial regulation.

\section{SPATIAL REGULATION OF SEPTUM PLACEMENT}

Two systems that employ negative regulation to spatially control division site selection have been identified and extensively studied in E. coli and B. subtilis. The nucleoid occlusion (NO) system acts as an anti-guillotine system to protect the nucleoid from aberrant Z-ring formation. The second regulatory system employed by E. coli and B. subtilis is the Min system. The Min system of E. coli consists of MinCDE, which collectively prevents division form occurring at the cell poles (for review see Lutkenhaus, 2007). This pole-to-pole oscillating system involves MinE activation of MinD ATPase, resulting in MinD release from the membrane which is closely followed by MinC, the actual inhibitor of FtsZ polymerization, The Min system of B. subtilis is less dynamic than that of E. coli (for review see Bramkamp and Van Baarle, 2009). Here, the Min system consists of the topological determinant DivIVA, an adaptor protein MinJ, MinD, and the FtsZ inhibitor MinC. In the absence of MinCD or MinJ disassembly of the divisome is impaired, resulting in the initiation of a new round of cytokinesis close to the original site of division, leading to rows of minicells (Van Baarle and Bramkamp, 2010). Thus, the Min system in B. subtilis is also required to disassemble the cytokinetic machinery.

\section{SPATIAL AND TEMPORAL REGULATION OF DIVISION AND CHROMOSOME SEGREGATION BY THE MinD/ParA PROTEIN FAMILY}

Corynebacterineae do not encode a Min system, however MinD related proteins are found in C. glutamicum and M. tuberculosis, for example ParA proteins. The highly conserved ParAB system has been shown in a number of organisms to be necessary for segregation of the oriC regions, as well as overall chromosome organization with respect to the oriC/terC localization (Wang et al., 2013). The tripartite partitioning system comprises of two trans-acting proteins, encoded in an operon (parA and parB, respectively), and cis-acting "centromere-like" elements. After initiation of chromosome replication, the ParB protein binds the centromere-like element parS forming a nucleoprotein complex (Funnell, 1988). Interaction with ParB proteins stimulates the ATPase activity of the ParA Walker type P-loop ATPase activating the molecular switch that regulates ParA localization and activity. In the ATP bound form ParA dimerizes and binds non-specifically to DNA while ParA-ADP does not bind DNA (Leonard et al., 2005; Murray and Errington, 2008). In B. subtilis, ParA-ADP (Soj) regulates DNA replication initiation by direct interaction with DnaA (Scholefield et al., 2012). Although still under debate, ParA has been implicated in providing the driving force, either through a pulling or pushing mechanisms, for oriC segregation (Ptacin and Shapiro, 2010; Schofield et al., 2010; Vecchiarelli et al., 2010).

In $C$. crescentus, where cell division is strictly coordinated with cell division, the Par system is essential (Mohl and Gober, 1997). On the contrary, par deletion mutants in B. subtilis exhibit only mild segregation defects (Ireton et al., 1994; Lin and Grossman, 1998; Webb et al., 1998). Mutation of components of the Par system in C. glutamicum or M. tuberculosis lead to a plethora of phenotypes including variable cell lengths, growth defects, 
multinucleoid cells as well as anucleate cells (Maloney et al., 2009; Donovan et al., 2010; Ginda et al., 2013).

In M. smegmatis, ParA is diffused in the cytoplasm, but additionally localizes as foci that are either unipolar, bipolar, or bipolar with a ParA focus around the midcell region (Ginda et al., 2013). The localization of ParB is somewhat unclear. Ginda and co-workers stated that ParB foci are found positioned in the vicinity of the cell poles, while Maloney and co-workers report ParB foci positioned at the cell poles (Maloney et al., 2009). Similarly, C. glutamicum ParA localizes as foci to the cell poles and forms patches over the chromosome, while ParB forms polar localized foci (Donovan et al., 2010). In C. glutamicum and M. smegmatis, cells lacking parA result in the production of DNA-free cells, extra ParB foci are produced and distribution of these ParB foci is altered, in addition to altered septum placement (Donovan et al., 2010; Ginda et al., 2013). These phenotypes would suggest that the Par system additionally plays a role in regulating replication initiation and division site positioning. Even though the division site placement is more variable in C. glutamicum and M. smegmatis/M. tuberculosis compared to B. subtilis and E. coli, regulatory mechanisms must exist as the divisome is positioned within a range of the precise midcell in the vast majority of cells (Aldridge et al., 2012; Joyce et al., 2012; Donovan et al., 2013; Santi et al., 2013). It has been reported that the divisome often assembles over the (unsegregated) nucleoid suggesting that a NO system does not exist in C. glutamicum or M. tuberculosis and also that DNA translocases play an important role in the removal of DNA from the invaginating division septum (Ramos et al., 2005; Donovan et al., 2013; Singh et al., 2013).

The generation of unequal sized daughter cells after cell division in M. smegmatis has been proposed to be the consequence of asymmetric polar growth after precise positioning of the nascent division septum at midcell (Aldridge et al., 2012; Joyce et al., 2012). On the contrary, two recent reports suggested that daughter cell asymmetry results from acentric placement of the Z-ring slightly closer to the new cell pole and is not influenced by asymmetric polar growth (Santi et al., 2013; Singh et al., 2013). In C. glutamicum, asymmetric polar cell growth has been observed with slightly elevated growth at the old pole, however the localization of FtsZ on a single cell level has not been investigated, to date (Sieger et al., 2013).

Single cell analysis of live C. glutamicum cells revealed that cell division does not normally occur close to the cell poles (Donovan et al., 2013). Given that the oriC region of the chromosome is speculated to be tethered at the cell pole through an interaction between the ParB-oriC nucleoprotein complex and the polar growth determinant DivIVA, divisions close to the cell poles would ultimately lead to chromosome guillotining (Donovan et al., 2012; Ginda et al., 2013). It should be noted that M. smegmatis polar ParA foci interacts with Wag31, however the consequence of this interaction is not clear, yet (Ginda et al., 2013). When the organization of the C. glutamicum nucleoid is compromised by mutation in the Par system, the placement of the division site is much more varied (Donovan et al., 2013). In addition, the growth rate is impaired in cells lacking parA or parB and also the timing of division events is much more variable, suggesting that chromosome segregation is coupled to cell growth and division (Donovan et al., 2013). This is not the case in B. subtilis par mutants, likely as a consequence of overlapping systems that ensure the fidelity of spatial regulation of the division septum.

\section{ParA-LIKE PROTEINS AND CELL DIVISION}

Not all bacteria that divide in a medial fashion encode a Min or NO system, for example C. crescentus. In C. crescentus, MipZ, which is a member of the ParA/MinD family, spatially regulates Z-ring assembly by stimulating the GTPase activity of FtsZ and inhibiting polymerization (for review see Thanbichler, 2010). MipZ localizes as a gradient that moves with the replicated sister origin to the old cell pole, where FtsZ is localized. Similar to other members of the ParA/MinD family, regulation of MipZ is nucleotide dependent (Kiekebusch et al., 2012). More recently, another ParA-like protein was implicated in positively regulating division site selection in Myxococcus xanthus a rod-shaped $\delta$-proteobacterium. This protein, PomZ localizes the nascent division site before FtsZ and is necessary for recruitment of the FtsZ (Treuner-Lange et al., 2013).

While both C. glutamicum and M. tuberculosis encode the canonical ParAB partitioning system, C. glutamicum encodes one additional ParA-like protein, whereas M. tuberculosis has two ParA-like proteins (Maloney et al., 2009; Donovan et al., 2010). The transcription profiling that identified two M. tuberculosis ZipA-like proteins additionally identified two MinD/ParA-like proteins (Rv1708 and Rv3660c) (Slayden et al., 2006). One of these proteins (Rv1708) is homologous to the orphan ParA-like protein found in C. glutamicum (PldP, Cg1610). The chromosomal location as well as a complete lack of a partner ParB protein would suggest that the orphan ParA-like protein is not, or not strongly, involved in chromosome segregation. A mutant deleted for pldP is not significantly impaired in chromosome segregation, however cell lengths are more variable, ranging from significantly longer to small, DNA free minicells (Donovan et al., 2010). The pldP mini cell phenotype is reminiscent of B. subtilis or E. coli min mutants. Lending to the notion that PldP plays a role in cell divisions, expression of $p l d P-c f p$ as a single copy from the native locus shows PldP foci at the nascent division site along with weaker signals that might be a result of binding to the nucleoid. Nonetheless, further work needs to be carried out to establish if PldP plays a role in regulating the localization of the Z-ring.

Comparison of the PldP sequence with ParA's and MinD's from other organisms reveals that the residues required for ATPbinding and hydrolysis, as well as DNA binding are conserved in PldP (Figure 1). Alternatively, recruitment might be a result of direct protein-protein interactions between PldP and other, as of yet unidentified, divisome components. Overall, members of the ParA/MinD protein family seem to play an important role in regulating cell cycle events, be it chromosome segregation, cell division, or both.

\section{REGULATION OF CELL DIVISION THROUGH PROTEIN PHOSPHORYLATION}

Reversible protein phosphorylation is a fundamental mechanism to regulate protein activity and is commonly used by bacteria to sense and rapidly respond to changing environmental 


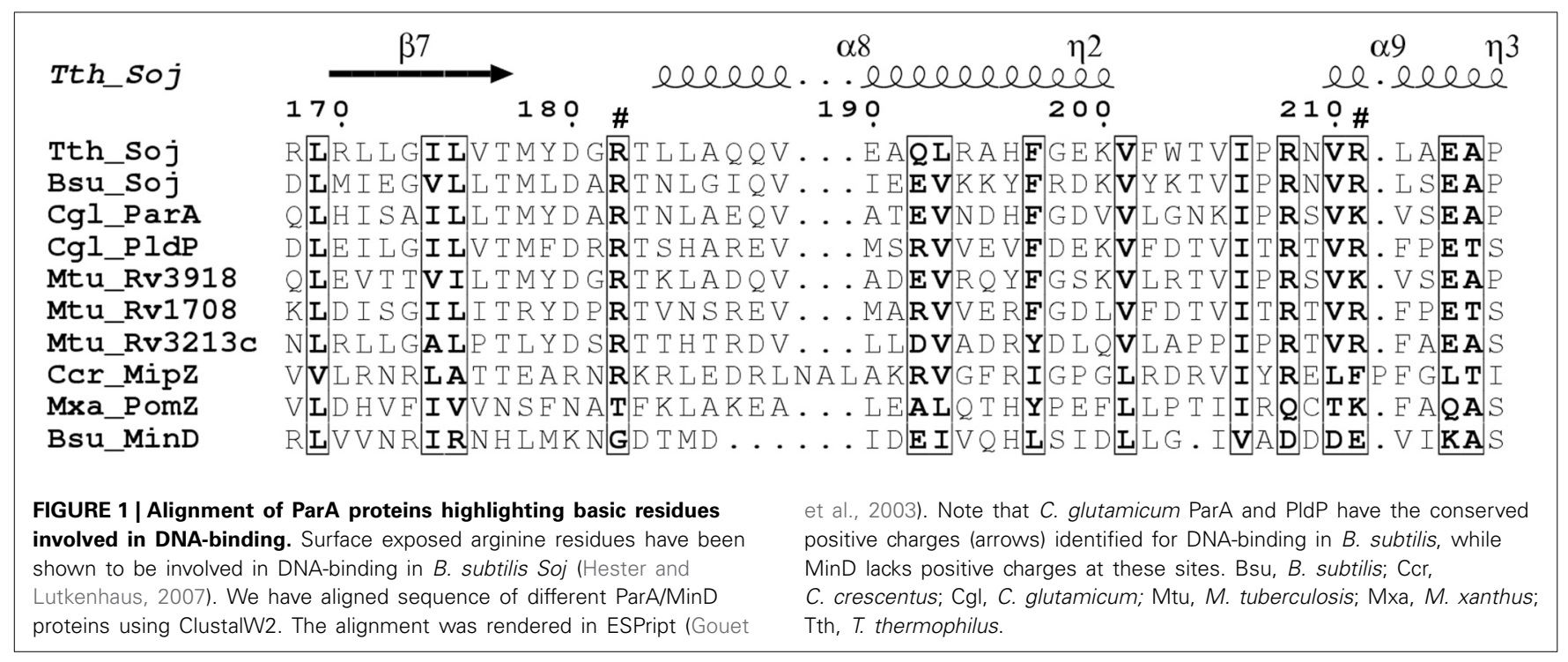

conditions as well as cell cycle events and control cellular function (Greenstein et al., 2005; Burnside and Rajagopal, 2012). Prokaryotic counterparts of the eukaryotic serine/threonine protein kinases (STPK) have emerged as important regulators of numerous cellular processes, such as cytokinesis as well as regulation of cell growth and shape (Molle and Kremer, 2010). Actinobacteria encode varying numbers of kinases, 4 in C. glutamicum and 11 in M. tuberculosis (Cole et al., 1998; Ikeda and Nakagawa, 2003; Kalinowski et al., 2003). In both C. glutamicum and M. tuberculosis, two of the kinases ( $\mathrm{PknA}$ and $\mathrm{PknB}$ ) are found in an operon with RodA (lipid II flipase) and PbpA (for review see Molle and Kremer, 2010).

The four eukaryotic-like Ser/Thr protein kinases (STPKs) encoded in C. glutamicum are designated PknA; $\mathrm{PknB}, \mathrm{PknL}$, and PknG, in analog to the Mycobacteria STPK's. With the exception of PknG, all the STPKs are predicted membrane integral proteins (Fiuza et al., 2008; Schultz et al., 2009). Furthermore, PknB and PknL have several PASTA (penicillinbinding protein and serine/threonine kinase associated) domains at their extra-cytoplasmic terminus, probably sensing peptidoglycan components, inducing dimerization and subsequent phosphorylation. In addition, a single gene ( $p p p)$ coding for a phospho-serine/threonine protein phosphatase was annotated on the C. glutamicum genome (Ikeda and Nakagawa, 2003; Kalinowski et al., 2003). In Mycobacterium and Corynebacterium, the operon encoding $p k n A$ and $p k n B$ genes also encodes for proteins involved in cell peptidoglycan synthesis suggesting a functional relationship between the STPK's and cell morphology and division.

The extracellular PASTA domain of B. subtilis Ser/Thr kinase PrkC binds peptidoglycan and stimulates germination of spores (Shah et al., 2008). In M. tuberculosis, the midcell and polar localization of $\mathrm{PknB}$ requires the extracytoplasmic PASTA domain (Mir et al., 2011). This domain has been proposed to bind peptidoglycan precursors or hydrolysis products, leading to a concentration of $\mathrm{PknB}$ at regions of the cell where cell growth occurs, namely the cell poles and division septa (Mir et al.,

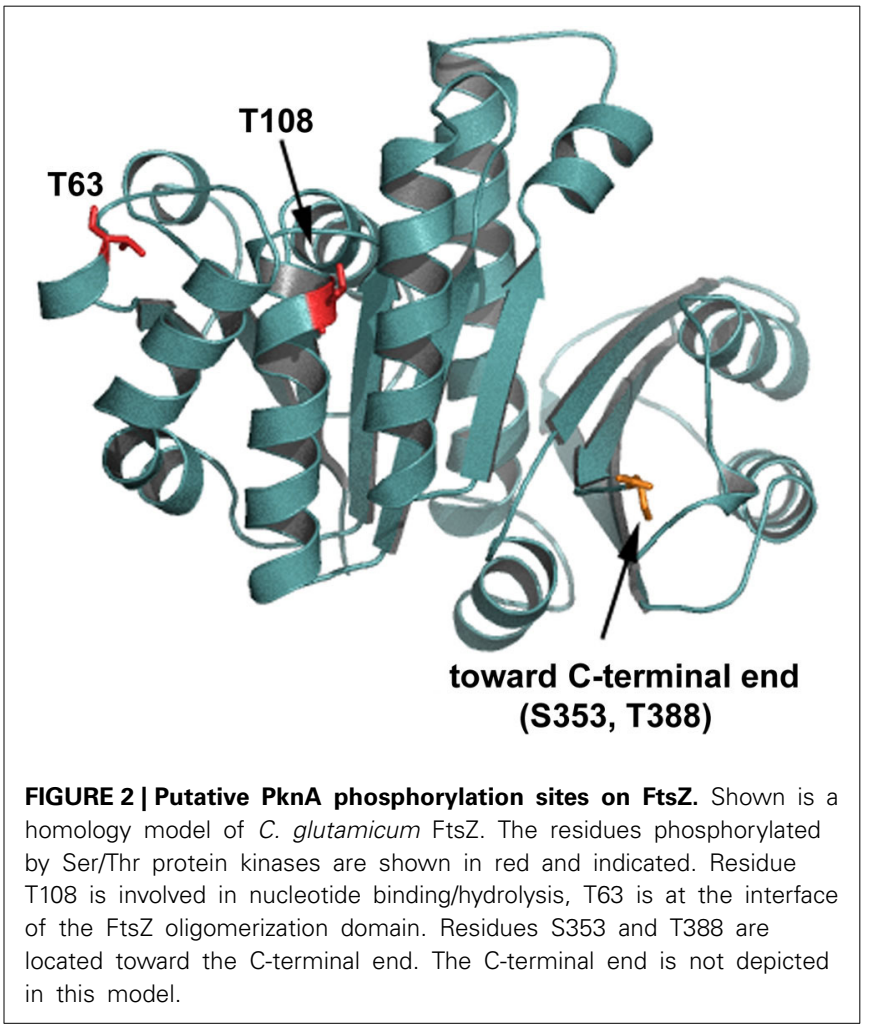

2011). Increased local concentration of $\mathrm{PknB}$ might facilitate dimerization and activation, subsequently playing a role in regulating cell growth and division. Both $\mathrm{PbpA}$, a peptidoglycan synthesizing enzyme localized to the septum and important for cell division (Dasgupta et al., 2006), and Wag31 have been identified as substrates of PknB (Kang et al., 2005; Dasgupta et al., 2006). Alterations in the expression level of $p k n A$ or $p k n B$ lead to altered morphology, including growth from ectopic sites (Kang et al., 2005).

Initial characterization of C. glutamicum STPKs revealed that deletion mutants, in all combinations, are viable with the 
exception of a $p k n A B$ mutant (Schultz et al., 2009). While growth rates of the single STPK's mutants are comparable to wild type, the mutant cells are elongated suggesting a role in cytokinesis and cell morphogenesis. This was particularly evident in cells lacking $p p p$, which have severe morphology and growth defects (Schultz et al., 2009). In line with these observations, apical growth is abolished upon overexpression of $p k n A$ or $p k n B$ (Fiuza et al., 2008). The cell division protein FtsZ was identified as an in vivo target for the phosphatase $\mathrm{Ppp}$ and in vitro phosphorylation by $\mathrm{PknA}, \mathrm{PknB}$, and $\mathrm{PknL}$ (Schultz et al., 2009). Four phosphorylation sites were identified (FtsZ ${ }^{\mathrm{T} 108}$ phosphorylated by PknA and FtsZ ${ }^{\mathrm{T} 63}, \mathrm{FtsZ}^{\mathrm{S} 353}$, and $\mathrm{FtsZ}^{\mathrm{T} 388}$ phosphorylated by $\mathrm{PknL}$ ). If the sites of FtsZ phosphorylation are mapped onto a 3D model of C. glutamicum FtsZ it becomes obvious that all four major phosphorylation sites could affect different functions of FtsZ (Figure 2). Residue T108 is involved in nucleotide binding/hydrolysis, T63 is at the interface of the FtsZ oligomerization domain and residues S353 and T388 are located toward the C-terminal end. It is easy to envision that the different sites may contribute to specific cellular functions. The C-terminal part of FtsZ is most likely an interaction domain to recruit downstream proteins to the site of septation (Haney et al., 2001). Although not completely understood, it is clear that STPK play an important regulatory role in cell division in Actinobacteria (for review see Molle and Kremer, 2010). Highlighting the degree of conservation in Actinobacteria, the genetic organization of the gene cluster encoding $p k n A$ and $p k n B$ is similar in C. glutamicum, M. tuberculosis and S. coelicolor (Boitel et al., 2003; Schultz et al., 2009). Along with cell division/cell wall biosynthesis genes, this cluster encodes two forkhead-associated (FHA) domain containing proteins. Studies in M. tuberculosis revealed that one of these FHA domain containing proteins (FhaA (Rv0020c)) negatively

\section{C. glutamicum}

A Old Pole

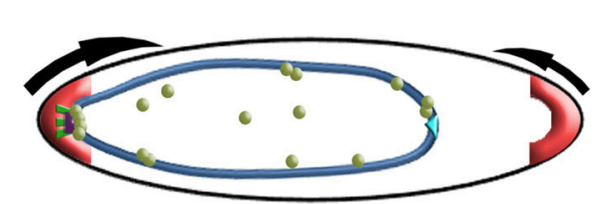

B

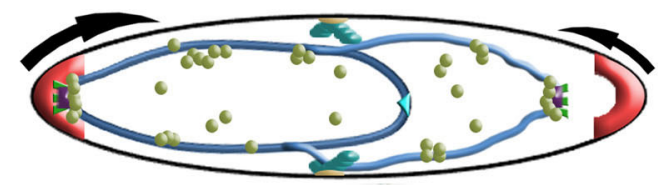

C

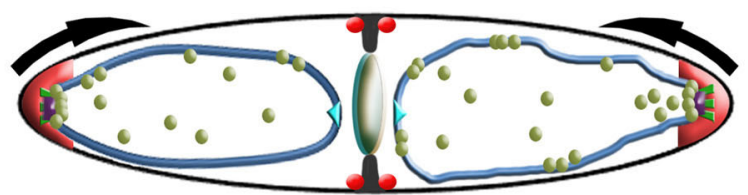

B. subtilis
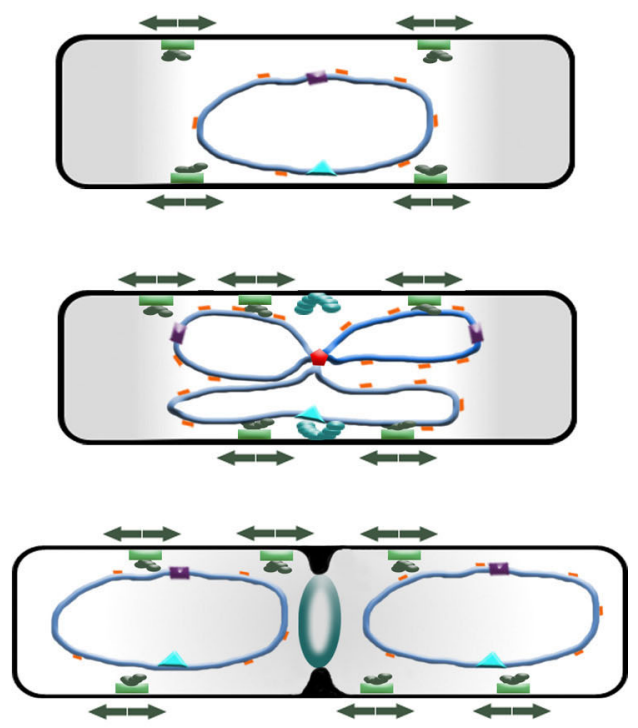

\section{loric $\triangle$ terC $\rightarrow \mathrm{FtsZ}$ MreB and elongasome}

FIGURE 3 | Comparison of cell division in C. glutamicum and B. subtilis. (A) Directly after cell division, one cell pole contains a ParB-bound origin that is tethered at the old cell pole through interaction with the polar growth determinant DivIVA. At this stage of the cell cycle, we speculate that polar growth is asymmetric with the pole lacking a tethered origin (young pole) growing slower than origin bound pole (arrows). In B. subtilis, the post-divisional cell contains a centrally located nucleoid with the oriC and ter $C$ also found positioned at the midcell. (B) Initiation of chromosome replication gives rise to duplication of the oriC. In C. glutamicum, the newly duplicated oriC is bound by $\operatorname{Par} B$, then ParA is recruited and the oriC is segregated to the opposite cell pole. FtsZ assembles into a Z-ring prior to complete segregation of the chromosome. The Z-ring does not always assemble precisely at midcell. The orphan ParA-like protein, PldP localizes to the division site, where it might function to spatially regulate cell division. In

\section{PIdP \\ VII ParB

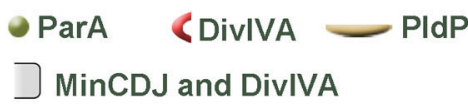 \\ replisome $]$ MinCDJ and DivIVA}

B. subtilis a centrally positioned replisome duplicates the chromosome. While the Min system protects the poles and Noc protects the chromosome from aberrant Z-ring assembly, some aspect of replication initiation positively influences midcell localization of the Z-ring (note that DivIVA is not part of the Min system here). Contrary to the asymmetric polar growth in C. glutamicum, B. subtilis grow at a uniform rate along the lateral axis (arrows). (C) In C. glutamicum, the sister origin is tethered at the cell pole by an interaction with DivIVA. This interaction then leads to an increase in growth from this pole (arrow). Polar growth, in addition with bulk chromosome segregation mechanisms, would aid in segregating the chromosomes. As the septum invaginates, DivIVA begins to localize at the site of division. In B. subtilis, the Min system moves from the cell poles to the invaginating septum. The midcell localized Min system prevents the divisome from reassembling near to an old division site. 
regulates the activity of MviN (a pseudokinase essential for peptidoglycan biosynthesis and growth), after PknB transphosphorylation (Gee et al., 2012). The second FHA domain containing protein (Rv0019c) is phosphorylated by $\mathrm{PknA}$ and has been proposed to interact with FtsZ, and hence has been renamed FtsZ interacting protein A, FipA (Sureka et al., 2010). The FHA domain of FipA is necessary for interaction with $\mathrm{PknA}$ and under oxidative stress conditions phosphorylated FipA is essential for FtsZ localization. The two FHA domain containing genes encoded on the C. glutamicum pkn cluster, (cg0064 (fhaA) and $\operatorname{cg} 0063(f h a B))$ have not been addressed in much detail, however recently it was established that FhaB is phosphorylated by $\mathrm{PknA}$ and $\mathrm{PknL}$, in vitro (Letek et al., 2012). It remains to be established if these C. glutamicum FHA domain containing proteins play a role in cell division and cell shape determination. Taken together, it appears that STPKs play a role in regulating cell growth and morphology, along with cell division in both Corynebacteria and Mycobacteria. Additionally, STPKs play a role in pathogenicity and cell survival (for review see Molle and Kremer, 2010).

\section{CONCLUSION AND OUTLOOK}

In recent years, advances have been made in understanding the intracellular organization and regulation of actinobacterial cells. Although all the components and regulatory systems involved in spatial and temporal regulation of cytokinesis have not been identified and characterized yet, it is clear that cell division differs in many ways to that of the long-standing model organisms. With the new era of live cell imaging and single cell analysis it will be possible to ascertain the role(s) of the putative Corynebacterineae cell division proteins.

In new-born C. glutamicum cells, we speculate that the oriC is orientated toward the old cell pole, where it is tethered in position through an interaction between DivIVA and the ParB-oriC nucleoprotein complex. On the contrary, the oriC in B. subtilis and E. coli is found at midcell directly after division. There is an increasing body of evidence suggesting that replication initiation (and subcellular localization of the replication machinery) and midcell Z-ring assembly are coordinated. Using an outgrowing spore system to synchronize $B$. subtilis cells it was shown that Z-rings assemble asymmetrically at one side of the nucleoid when replication is completely inhibited or halted shortly after the oriC region has been replicated (Harry et al., 1999; Regamey et al., 2000). However, permitting replication initiation but blocking of DNA synthesis resulted in midcell assembly of Z-rings. From these observations it appears that the early stages of chromosome initiation positively influence midcell localization of FtsZ. In C. glutamicum, FtsZ assembles in the vicinity of the midcell region before the chromosomes have been completely segregated (Figure 3). It seems likely that the localization of the oriC and hence subcellular address of the replisome impact on the positioning of FtsZ. In line with this prospect, the positioning of division septa in $C$. glutamicum are more variable in cells lacking parA or parB, hinting that either the overall chromosome organization or segregation of the oriC regions might coordinate cell division and replication / segregation of the chromosomes. We additionally speculate that segregation of the oriC region to the opposite cell pole might influence the rate of polar growth at the new cell pole through. Recently, acyl-acyl carrier protein phosphate acyltransferase (PlsX) an enzyme involved in phospholipid and fatty acid synthesis in B. subtilis was identified as an interaction partner of FtsA and thus is a novel component of the divisome machinery (Takada et al., 2014). In the absence of plsX, Z-rings assemble at aberrant sites. More interestingly, the localization of PlsX is affected by DNA replication progression. Once again, the complexity of spatio-temporal regulation of cell division is highlighted. All in all, bacteria have evolved multiple, probably partially redundant mechanisms to regulate cell division. In C. glutamicum, the ParB-oriC nucleo-protein complex is positioned at the cell pole, where it is tethered by interaction with the polar growth determinant DivIVA. Given that reduced expression of divIVA phenocopies a parB deletion mutant, we speculate that anchoring the replicated origin at the cell pole influences the growth rate of the pole (Donovan et al., 2012) (Figure 3). Asymmetry in polar growth has been observed in C. glutamicum (Sieger et al., 2013). It will be interesting to determine if the slower growing pole is the pole void of an anchored origin.

\section{ACKNOWLEDGMENTS}

This paper is dedicated to Prof. Dr. R. Krämer (University of Cologne) on the occasion of his retirement.

\section{REFERENCES}

Adams, D. W., and Errington, J. (2009). Bacterial cell division: assembly, maintenance and disassembly of the Z ring. Nat. Rev. Microbiol. 7, 642-653. doi: 10.1038/nrmicro2198

Aldridge, B. B., Fernandez-Suarez, M., Heller, D., Ambravaneswaran, V., Irimia, D., Toner, M., et al. (2012). Asymmetry and aging of mycobacterial cells lead to variable growth and antibiotic susceptibility. Science 335, 100-104. doi: $10.1126 /$ science. 1216166

Al-Khafaji, Z. M. (2013). In silico investigation of rv hypothetical proteins of virulent strain Mycobacterium tuberculosis H37Rv. Ind. J. Pharm. Biol. Res. 1, 81-88.

Anderson, D. E., Gueiros-Filho, F. J., and Erickson, H. P. (2004). Assembly dynamics of FtsZ rings in Bacillus subtilis and Escherichia coli and effects of FtsZregulating proteins. J. Bacteriol. 186, 5775-5781. doi: 10.1128/JB.186.17.57755781.2004

Arends, S. J., Kustusch, R. J., and Weiss, D. S. (2009). ATP-binding site lesions in FtsE impair cell division. J. Bacteriol. 191, 3772-3784. doi: 10.1128/JB.00179-09

Arends, S. J., Williams, K., Scott, R. J., Rolong, S., Popham, D. L., and Weiss, D. S. (2010). Discovery and characterization of three new Escherichia coli septal ring proteins that contain a SPOR domain: DamX, DedD, and RlpA. J. Bacteriol. 192, 242-255. doi: 10.1128/JB.01244-09

Beall, B., Löwe, M., and Lutkenhaus, J. (1988). Cloning and characterization of Bacillus subtilis homologs of Escherichia coli cell division genes fts $Z$ and ftsA. J. Bacteriol. 170, 4855-4864.

Beall, B., and Lutkenhaus, J. (1992). Impaired cell division and sporulation of a Bacillus subtilis strain with the ftsA gene deleted. J. Bacteriol. 174, 2398-2403.

Begg, K. J., Dewar, S. J., and Donachie, W. D. (1995). A new Escherichia coli cell division gene, ftsK. J. Bacteriol. 177, 6211-6222.

Bernhardt, T. G., and De Boer, P. A. (2003). The Escherichia coli amidase AmiC is a periplasmic septal ring component exported via the twin-arginine transport pathway. Mol. Microbiol. 48, 1171-1182. doi: 10.1046/j.1365-2958.2003.03511.x

Bernhardt, T. G., and De Boer, P. A. (2004). Screening for synthetic lethal mutants in Escherichia coli and identification of EnvC (YibP) as a periplasmic septal ring factor with murein hydrolase activity. Mol. Microbiol. 52, 1255-1269. doi: 10.1111/j.1365-2958.2004.04063.x

Bernhardt, T. G., and De Boer, P. A. (2005). SImA, a nucleoid-associated, FtsZ binding protein required for blocking septal ring assembly over chromosomes in $E$. coli. Mol. Cell 18, 555-564. doi: 10.1016/j.molcel.2005.04.012 
Bi, E. F., and Lutkenhaus, J. (1991). FtsZ ring structure associated with division in Escherichia coli. Nature 354, 161-164. doi: 10.1038/354161a0

Bi, E., and Lutkenhaus, J. (1993). Cell division inhibitors SulA and MinCD prevent formation of the FtsZ ring. J. Bacteriol. 175, 1118-1125.

Boitel, B., Ortiz-Lombardia, M., Duran, R., Pompeo, F., Cole, S. T., Cervenansky, C., et al. (2003). PknB kinase activity is regulated by phosphorylation in two Thr residues and dephosphorylation by PstP, the cognate phospho-Ser/Thr phosphatase, in Mycobacterium tuberculosis. Mol. Microbiol. 49, 1493-1508. doi: 10.1046/j.1365-2958.2003.03657.x

Bramkamp, M., Emmins, R., Weston, L., Donovan, C., Daniel, R. A., and Errington, J. (2008). A novel component of the division-site selection system of Bacillus subtilis and a new mode of action for the division inhibitor MinCD. Mol. Microbiol. 70, 1556-1569. doi: 10.1111/j.1365-2958.2008.06501.x

Bramkamp, M., and Van Baarle, S. (2009). Division site selection in rodshaped bacteria. Curr. Opin. Microbiol. 12, 683-688. doi: 10.1016/j.mib.2009. 10.002

Buddelmeijer, N., Judson, N., Boyd, D., Mekalanos, J. J., and Beckwith, J. (2002). YgbQ, a cell division protein in Escherichia coli and Vibrio cholerae, localizes in codependent fashion with FtsL to the division site. Proc. Natl. Acad. Sci. U.S.A. 99, 6316-6321. doi: 10.1073/pnas.092128499

Burger, A., Sichler, K., Kelemen, G., Buttner, M., and Wohlleben, W. (2000). Identification and characterization of the mre gene region of Streptomyces coelicolor A3(2). Mol. Gen. Genet. 263, 1053-1060. doi: 10.1007/s0043800 50034

Burnside, K., and Rajagopal, L. (2012). Regulation of prokaryotic gene expression by eukaryotic-like enzymes. Curr. Opin. Microbiol. 15, 125-131. doi: 10.1016/j.mib.2011.12.006

Camberg, J. L., Hoskins, J. R., and Wickner, S. (2009). ClpXP protease degrades the cytoskeletal protein, FtsZ, and modulates FtsZ polymer dynamics. Proc. Natl. Acad. Sci. U.S.A. 106, 10614-10619. doi: 10.1073/pnas.0904886106

Cha, J. H., and Stewart, G. C. (1997). The divIVA minicell locus of Bacillus subtilis. J. Bacteriol. 179, 1671-1683.

Chastanet, A., and Carballido-Lopez, R. (2012). The actin-like MreB proteins in Bacillus subtilis: a new turn. Front. Biosci. (Schol. Ed.) 4:1582-1606. doi: $10.2741 /$ S354

Chauhan, A. A. (2006). Interference of Mycobacterium tuberculosis cell division by Rv2719c, a cell wall hydrolase. Mol. Microbiol. 62, 132-147. doi: 10.1111/j.13652958.2006.05333.x

Chauhan, A., Madiraju, M. V., Fol, M., Lofton, H., Maloney, E., Reynolds, R., et al. (2006). Mycobacterium tuberculosis cells growing in macrophages are filamentous and deficient in FtsZ rings. J. Bacteriol. 188, 1856-1865. doi: 10.1128/JB.188.5.1856-1865.2006

Cole, S. T., Brosch, R., Parkhill, J., Garnier, T., Churcher, C., Harris, D., et al. (1998). Deciphering the biology of Mycobacterium tuberculosis from the complete genome sequence. Nature 393, 537-544. doi: 10.1038/31159

Corbin, B. D., Wang, Y., Beuria, T. K., and Margolin, W. (2007). Interaction between cell division proteins FtsE and FtsZ. J. Bacteriol. 189, 3026-3035. doi: 10.1128/JB.01581-06

Costa, A., Hood, I. V., and Berger, J. M. (2013). Mechanisms for initiating cellular DNA replication. Annu. Rev. Biochem. 82, 25-54. doi: 10.1146/annurevbiochem-052610-094414

Daniel, R. A., and Errington, J. (2003). Control of cell morphogenesis in bacteria: two distinct ways to make a rod-shaped cell. Cell 113, 767-776. doi: 10.1016/S0092-8674(03)00421-5

Daniel, R. A., Harry, E. J., and Errington, J. (2000). Role of penicillin-binding protein PBP 2B in assembly and functioning of the division machinery of Bacillus subtilis. Mol. Microbiol. 35, 299-311. doi: 10.1046/j.1365-2958.2000. 01724.x

Daniel, R. A., Harry, E. J., Katis, V. L., Wake, R. G., and Errington, J. (1998). Characterization of the essential cell division gene $f t s L(y I I D)$ of Bacillus subtilis and its role in the assembly of the division apparatus. Mol. Microbiol. 29, 593-604. doi: 10.1046/j.1365-2958.1998.00954.x

Dasgupta, A., Datta, P., Kundu, M., and Basu, J. (2006). The serine/threonine kinase PknB of Mycobacterium tuberculosis phosphorylates PBPA, a penicillinbinding protein required for cell division. Microbiology 152, 493-504. doi: $10.1099 /$ mic. $0.28630-0$

Datta, P., Dasgupta, A., Bhakta, S., and Basu, J. (2002). Interaction between FtsZ and FtsW of Mycobacterium tuberculosis. J. Biol. Chem. 277, 24983-24987. doi: 10.1074/jbc.M203847200
Datta, P., Dasgupta, A., Singh, A. K., Mukherjee, P., Kundu, M., and Basu, J. (2006). Interaction between FtsW and penicillin-binding protein 3 (PBP3) directs PBP3 to mid-cell, controls cell septation and mediates the formation of a trimeric complex involving FtsZ, FtsW and PBP3 in mycobacteria. Mol. Microbiol. 62, 1655-1673. doi: 10.1111/j.1365-2958.2006.05491.x

De Boer, P. A., Crossley, R. E., and Rothfield, L. I. (1989). A division inhibitor and a topological specificity factor coded for by the minicell locus determine proper placement of the division septum in E. coli. Cell 56, 641-649. doi: 10.1016/00928674(89)90586-2

Deng, L. L., Humphries, D. E., Arbeit, R. D., Carlton, L. E., Smole, S. C., and Carroll, J. D. (2005). Identification of a novel peptidoglycan hydrolase CwlM in Mycobacterium tuberculosis. Biochim. Biophys. Acta 1747, 57-66. doi: 10.1016/j.bbapap.2004.09.021

De Pedro, M. A., Donachie, W. D., Holtje, J. V., and Schwarz, H. (2001). Constitutive septal murein synthesis in Escherichia coli with impaired activity of the morphogenetic proteins RodA and penicillin-binding protein 2. J. Bacteriol. 183, 4115-4126. doi: 10.1128/JB.183.14.4115-4126.2001

Dominguez-Cuevas, P., Porcelli, I., Daniel, R. A., and Errington, J. (2013). Differentiated roles for MreB-actin isologues and autolytic enzymes in Bacillus subtilis morphogenesis. Mol. Microbiol. 89, 1084-1098. doi: 10.1111/mmi.12335

Donovan, C., Schauss, A., Krämer, R., and Bramkamp, M. (2013). Chromosome segregation impacts on cell growth and division site selection in Corynebacterium glutamicum. PLoS ONE 8:e55078. doi: 10.1371/journal.pone. 0055078

Donovan, C., Schwaiger, A., Krämer, R., and Bramkamp, M. (2010). Subcellular localization and characterization of the ParAB system from Corynebacterium glutamicum. J. Bacteriol. 192, 3441-3451. doi: 10.1128/JB.00214-10

Donovan, C., Sieger, B., Krämer, R., and Bramkamp, M. (2012). A synthetic Escherichia coli system identifies a conserved origin tethering factor in Actinobacteria. Mol. Microbiol. 84, 105-116. doi: 10.1111/j.1365-2958.2012.08011.x

Duman, R., Ishikawa, S., Celik, I., Strahl, H., Ogasawara, N., Troc, P., et al. (2013). Structural and genetic analyses reveal the protein SepF as a new membrane anchor for the Z ring. Proc. Natl. Acad. Sci. U.S.A. 110, E4601-E4610. doi: 10.1073/pnas.1313978110

Durand-Heredia, J., Rivkin, E., Fan, G., Morales, J., and Janakiraman, A. (2012). Identification of ZapD as a cell division factor that promotes the assembly of FtsZ in Escherichia coli. J. Bacteriol. 194, 3189-3198. doi: 10.1128/JB.00176-12

Durand-Heredia, J. M., Yu, H. H., De Carlo, S., Lesser, C. F., and Janakiraman, A. (2011). Identification and characterization of ZapC, a stabilizer of the FtsZ ring in Escherichia coli. J. Bacteriol. 193, 1405-1413. doi: 10.1128/JB.01258-10

Dziadek, J., Rutherford, S. A., Madiraju, M. V., Atkinson, M. A., and Rajagopalan, M. (2003). Conditional expression of Mycobacterium smegmatis fts $Z$, an essential cell division gene. Microbiology 149, 1593-1603. doi: 10.1099/mic.0. 26023-0

Dziedzic, R., Kiran, M., Plocinski, P., Ziolkiewicz, M., Brzostek, A., Moomey, M., et al. (2010). Mycobacterium tuberculosis ClpX interacts with FtsZ and interferes with FtsZ assembly. PLoS ONE 5:e11058. doi: 10.1371/journal.pone.0011058

Ebersbach, G., Galli, E., Møller-Jensen, J., Löwe, J., and Gerdes, K. (2008). Novel coiled-coil cell division factor ZapB stimulates $Z$ ring assembly and cell division. Mol. Microbiol. 68, 720-735. doi: 10.1111/j.1365-2958.2008.06190.x

Edwards, D. H., and Errington, J. (1997). The Bacillus subtilis DivIVA protein targets to the division septum and controls the site specificity of cell division. Mol. Microbiol. 24, 905-915. doi: 10.1046/j.1365-2958.1997.3811764.x

Ehlert, K., and Höltje, J. V. (1996). Role of precursor translocation in coordination of murein and phospholipid synthesis in Escherichia coli. J. Bacteriol. 178, 6766-6771.

Favrot, L., and Ronning, D. R. (2012). Targeting the mycobacterial envelope for tuberculosis drug development. Expert Rev. Anti Infect. Ther. 10, 1023-1036. doi: 10.1586/eri.12.91

Fiuza, M., Canova, M. J., Zanella-Cleon, I., Becchi, M., Cozzone, A. J., Mateos, L. M., et al. (2008). From the characterization of the four serine/threonine protein kinases $(\mathrm{PknA} / \mathrm{B} / \mathrm{G} / \mathrm{L})$ of Corynebacterium glutamicum toward the role of PknA and PknB in cell division. J. Biol. Chem. 283, 18099-18112. doi: $10.1074 /$ jbc.M802615200

Flärdh, K. (2010). Cell polarity and the control of apical growth in Streptomyces. Curr. Opin. Microbiol. 13, 758-765. doi: 10.1016/j.mib.2010.10.002

Funnell, B. E. (1988). Mini-P1 plasmid partitioning: excess ParB protein destabilizes plasmids containing the centromere parS. J. Bacteriol. 170, 954-960. 
Galli, E., and Gerdes, K. (2010). Spatial resolution of two bacterial cell division proteins: ZapA recruits ZapB to the inner face of the Z-ring. Mol. Microbiol. 76, 1514-1526. doi: 10.1111/j.1365-2958.2010.07183.x

Gamba, P., Veening, J. W., Saunders, N. J., Hamoen, L. W., and Daniel, R. A. (2009). Two-step assembly dynamics of the Bacillus subtilis divisome. J. Bacteriol. 191, 4186-4194. doi: 10.1128/JB.01758-08

Garti-Levi, S., Hazan, R., Kain, J., Fujita, M., and Ben-Yehuda, S. (2008). The FtsEX ABC transporter directs cellular differentiation in Bacillus subtilis. Mol. Microbiol. 69, 1018-1028. doi: 10.1111/j.1365-2958.2008.06340.x

Gee, C. L., Papavinasasundaram, K. G., Blair, S. R., Baer, C. E., Falick, A. M., King, D. S., et al. (2012). A phosphorylated pseudokinase complex controls cell wall synthesis in mycobacteria. Sci. Signal. 5, ra7. doi: 10.1126/scisignal.2002525

Gerding, M. A., Liu, B., Bendezu, F. O., Hale, C. A., Bernhardt, T. G., and De Boer, P. A. (2009). Self-enhanced accumulation of FtsN at division sites and roles for other proteins with a SPOR domain (DamX, DedD, and RlpA) in Escherichia coli cell constriction. J. Bacteriol. 191, 7383-7401. doi: 10.1128/JB. 00811-09

Ginda, K., Bezulska, M., Ziolkiewicz, M., Dziadek, J., Zakrzewska-Czerwinska, J., and Jakimowicz, D. (2013). ParA of Mycobacterium smegmatis co-ordinates chromosome segregation with the cell cycle and interacts with the polar growth determinant DivIVA. Mol. Microbiol. 87, 998-1012. doi: 10.1111/mmi.12146

Goley, E. D., Yeh, Y. C., Hong, S. H., Fero, M. J., Abeliuk, E., McAdams, H. H., et al. (2011). Assembly of the Caulobacter cell division machine. Mol. Microbiol. 80, 1680-1698. doi: 10.1111/j.1365-2958.2011.07677.x

Gouet, P., Robert, X., and Courcelle, E. (2003). ESPript/ENDscript: extracting and rendering sequence and $3 \mathrm{D}$ information from atomic structures of proteins. Nucleic Acids Res. 31, 3320-3323. doi: 10.1093/nar/gkg556

Gray, D. I., Gooday, G. W., and Prosser, J. I. (1990). Apical hyphal extension in Streptomyces coelicolor A3(2). J. Gen. Microbiol. 136, 1077-1084. doi: 10.1099/00221287-136-6-1077

Greenstein, A. E., Grundner, C., Echols, N., Gay, L. M., Lombana, T. N., Miecskowski, C. A., et al. (2005). Structure/function studies of Ser/Thr and Tyr protein phosphorylation in Mycobacterium tuberculosis. J. Mol. Microbiol. Biotechnol. 9, 167-181. doi: 10.1159/000089645

Gueiros-Filho, F. J., and Losick, R. (2002). A widely conserved bacterial cell division protein that promotes assembly of the tubulin-like protein FtsZ. Genes Dev. 16, 2544-2556. doi: 10.1101/gad.1014102

Guzman, L. M., Barondess, J. J., and Beckwith, J. (1992). FtsL, an essential cytoplasmic membrane protein involved in cell division in Escherichia coli. J. Bacteriol. 174, 7716-7728.

Haeusser, D. P., Lee, A. H., Weart, R. B., and Levin, P. A. (2009). ClpX inhibits FtsZ assembly in a manner that does not require its ATP hydrolysis-dependent chaperone activity. J. Bacteriol. 191, 1986-1991. doi: 10.1128/JB.01606-07

Haeusser, D. P., Schwartz, R. L., Smith, A. M., Oates, M. E., and Levin, P. A. (2004). EzrA prevents aberrant cell division by modulating assembly of the cytoskeletal protein FtsZ. Mol. Microbiol. 52, 801-814. doi: 10.1111/j.13652958.2004.04016.x

Hale, C. A., and De Boer, P. A. (1997). Direct binding of FtsZ to ZipA, an essential component of the septal ring structure that mediates cell division in E. coli. Cell 88, 175-185. doi: 10.1016/S0092-8674(00)81838-3

Hale, C. A., Shiomi, D., Liu, B., Bernhardt, T. G., Margolin, W., Niki, H., et al. (2011). Identification of Escherichia coli ZapC (YcbW) as a component of the division apparatus that binds and bundles FtsZ polymers. J. Bacteriol. 193, 1393-1404. doi: 10.1128/JB.01245-10

Hamoen, L. W., Meile, J. C., De Jong, W., Noirot, P., and Errington, J. (2006). SepF, a novel FtsZ-interacting protein required for a late step in cell division. Mol. Microbiol. 59, 989-999. doi: 10.1111/j.1365-2958.2005.04987.x

Handler, A. A., Lim, J. E., and Losick, R. (2008). Peptide inhibitor of cytokinesis during sporulation in Bacillus subtilis. Mol. Microbiol. 68, 588-599. doi: 10.1111/j.1365-2958.2008.06173.x

Haney, S. A., Glasfeld, E., Hale, C., Keeney, D., He, Z., and De Boer, P. (2001). Genetic analysis of the Escherichia coli FtsZ.ZipA interaction in the yeast two-hybrid system. Characterization of FtsZ residues essential for the interactions with ZipA and with FtsA. J. Biol. Chem. 276, 11980-11987. doi: 10.1074/jbc.M009810200

Harry, E. J., Rodwell, J., and Wake, R. G. (1999). Co-ordinating DNA replication with cell division in bacteria: a link between the early stages of a round of replication and mid-cell Z ring assembly. Mol. Microbiol. 33, 33-40. doi: 10.1046/j.1365-2958.1999.01439.x
Harry, E. J., and Wake, R. G. (1989). Cloning and expression of a Bacillus subtilis division initiation gene for which a homolog has not been identified in another organism. J. Bacteriol. 171, 6835-6839.

Heidrich, C., Templin, M. F., Ursinus, A., Merdanovic, M., Berger, J., Schwarz, H., et al. (2001). Involvement of N-acetylmuramyl-L-alanine amidases in cell separation and antibiotic-induced autolysis of Escherichia coli. Mol. Microbiol. 41, 167-178. doi: 10.1046/j.1365-2958.2001.02499.x

Hester, C. M., and Lutkenhaus, J. (2007). Soj (ParA) DNA binding is mediated by conserved arginines and is essential for plasmid segregation. Proc. Natl. Acad. Sci. U.S.A. 104, 20326-20331. doi: 10.1073/pnas.0705196105

Hett, E. C., Chao, M. C., Deng, L. L., and Rubin, E. J. (2008). A mycobacterial enzyme essential for cell division synergizes with resuscitation-promoting factor. PLoS Pathog. 4:e1000001. doi: 10.1371/journal.ppat.1000001

Hett, E. C., and Rubin, E. J. (2008). Bacterial growth and cell division: a mycobacterial perspective. Microbiol. Mol. Biol. Rev.72, 126-156, table of contents. doi: 10.1128/MMBR.00028-07

Horii, T., Ogawa, T., Nakatani, T., Hase, T., Matsubara, H., and Ogawa, H. (1981). Regulation of SOS functions: purification of E. coli LexA protein and determination of its specific site cleaved by the RecA protein. Cell 27, 515-522. doi: 10.1016/0092-8674(81)90393-7

Hottes, A. K., Shapiro, L., and McAdams, H. H. (2005). DnaA coordinates replication initiation and cell cycle transcription in Caulobacter crescentus. Mol. Microbiol. 58, 1340-1353. doi: 10.1111/j.1365-2958.2005.04912.x

Huang, K. H., Durand-Heredia, J., and Janakiraman, A. (2013). FtsZ ring stability: of bundles, tubules, crosslinks, and curves. J. Bacteriol. 195, 1859-1868. doi: 10.1128/JB.02157-12

Huisman, O., D'ari, R., and Gottesman, S. (1984). Cell-division control in Escherichia coli: specific induction of the SOS function SfiA protein is sufficient to block septation. Proc. Natl. Acad. Sci. U.S.A. 81, 4490-4494. doi: 10.1073/pnas.81.14.4490

Ikeda, M., and Nakagawa, S. (2003). The Corynebacterium glutamicum genome: features and impacts on biotechnological processes. Appl. Microbiol. Biotechnol. 62, 99-109. doi: 10.1007/s00253-003-1328-1

Ireton, K., Gunther, N. W. T., and Grossman, A. D. (1994). spo0J is required for normal chromosome segregation as well as the initiation of sporulation in Bacillus subtilis. J. Bacteriol. 176, 5320-5329.

Ishikawa, S., Kawai, Y., Hiramatsu, K., Kuwano, M., and Ogasawara, N. (2006). A new FtsZ-interacting protein, YlmF, complements the activity of FtsA during progression of cell division in Bacillus subtilis. Mol. Microbiol. 60, 1364-1380. doi: 10.1111/j.1365-2958.2006.05184.x

Jochmann, N., Kurze, A. K., Czaja, L. F., Brinkrolf, K., Brune, I., Huser, A. T., et al. (2009). Genetic makeup of the Corynebacterium glutamicum LexA regulon deduced from comparative transcriptomics and in vitro DNA band shift assays. Microbiology 155, 1459-1477. doi: 10.1099/mic.0.025841-0

Jorge, A. M., Hoiczyk, E., Gomes, J. P., and Pinho, M. G. (2011). EzrA contributes to the regulation of cell size in Staphylococcus aureus. PLoS ONE 6:e27542. doi: 10.1371/journal.pone.0027542

Joyce, G., Williams, K. J., Robb, M., Noens, E., Tizzano, B., Shahrezaei, V., et al. (2012). Cell division site placement and asymmetric growth in mycobacteria. PLoS ONE 7:e44582. doi: 10.1371/journal.pone.0044582

Kalinowski, J., Bathe, B., Bartels, D., Bischoff, N., Bott, M., Burkovski, A., et al. (2003). The complete Corynebacterium glutamicum ATCC 13032 genome sequence and its impact on the production of L-aspartate-derived amino acids and vitamins. J. Biotechnol. 104, 5-25. doi: 10.1016/S0168-1656(03) 00154-8

Kang, C. M., Abbott, D. W., Park, S. T., Dascher, C. C., Cantley, L. C., and Husson, R. N. (2005). The Mycobacterium tuberculosis serine/threonine kinases PknA and PknB: substrate identification and regulation of cell shape. Genes Dev. 19, 1692-1704. doi: 10.1101/gad.1311105

Kang, C. M., Nyayapathy, S., Lee, J. Y., Suh, J. W., and Husson, R. N. (2008). Wag31, a homologue of the cell division protein DivIVA, regulates growth, morphology and polar cell wall synthesis in mycobacteria. Microbiology 154, 725-735. doi: 10.1099/mic.0.2007/014076-0

Kawai, Y., Moriya, S., and Ogasawara, N. (2003). Identification of a protein, YneA, responsible for cell division suppression during the SOS response in Bacillus subtilis. Mol. Microbiol. 47, 1113-1122. doi: 10.1046/j.1365-2958.2003.03360.x

Kawai, Y., and Ogasawara, N. (2006). Bacillus subtilis EzrA and FtsL synergistically regulate FtsZ ring dynamics during cell division. Microbiology 152, 1129-1141. doi: 10.1099/mic.0.28497-0 
Keijser, B. J., Noens, E. E., Kraal, B., Koerten, H. K., and Van Wezel, G. P. (2003). The Streptomyces coelicolor $s s g B$ gene is required for early stages of sporulation. FEMS Microbiol. Lett. 225, 59-67. doi: 10.1016/S0378-1097(03) 00481-6

Kiekebusch, D., Michie, K. A., Essen, L. O., Löwe, J., and Thanbichler, M. (2012). Localized dimerization and nucleoid binding drive gradient formation by the bacterial cell division inhibitor MipZ. Mol. Cell 46, 245-259. doi: 10.1016/j.molcel.2012.03.004

Król, E., Van Kessel, S. P., Van Bezouwen, L. S., Kumar, N., Boekema, E. J., and Scheffers, D. J. (2012). Bacillus subtilis SepF binds to the C-terminus of FtsZ. PLOS ONE 7:e43293. doi: 10.1371/journal.pone.0043293

Leonard, T. A., Butler, P. J., and Löwe, J. (2005). Bacterial chromosome segregation: structure and DNA binding of the Soj dimer - a conserved biological switch. EMBO J. 24, 270-282. doi: 10.1038/s.emboj.7600530

Letek, M., Fiuza, M., Ordóñez, E., Villadangos, A. F., Ramos, A., Mateos, L. M., et al. (2008a). Cell growth and cell division in the rod-shaped actinomycete Corynebacterium glutamicum. Antonie Van Leeuwenhoek 94, 99-109. doi: $10.1007 /$ s10482-008-9224-4

Letek, M., Fiuza, M., Villadangos, A. F., Mateos, L. M., and Gil, J. A. (2012). Cytoskeletal proteins of Actinobacteria. Int. J. Cell Biol. 2012:905832. doi: $10.1155 / 2012 / 905832$

Letek, M., Ordóñez, E., Fiuza, M., Honrubia-Marcos, P., Vaquera, J., Gil, J. A., et al. (2007). Characterization of the promoter region of fts $Z$ from Corynebacterium glutamicum and controlled overexpression of FtsZ. Int. Microbiol. 10, 271-282. doi: $10.2436 / 20.1501 .01 .36$

Letek, M., Ordóñez, E., Vaquera, J., Margolin, W., Flärdh, K., Mateos, L. M., et al. (2008b). DivIVA is required for polar growth in the MreB-lacking rod-shaped actinomycete Corynebacterium glutamicum. J. Bacteriol. 190, 3283-3292. doi: 10.1128/JB.01934-07

Levin, P. A., Kurtser, I. G., and Grossman, A. D. (1999). Identification and characterization of a negative regulator of FtsZ ring formation in Bacillus subtilis. Proc. Natl. Acad. Sci. U.S.A. 96, 9642-9647. doi: 10.1073/pnas.96.17.9642

Levin, P. A., and Losick, R. (1994). Characterization of a cell division gene from Bacillus subtilis that is required for vegetative and sporulation septum formation. J. Bacteriol. 176, 1451-1459.

Levin, P. A., Margolis, P. S., Setlow, P., Losick, R., and Sun, D. (1992). Identification of Bacillus subtilis genes for septum placement and shape determination. J. Bacteriol. 174, 6717-6728.

Lin, D. C., and Grossman, A. D. (1998). Identification and characterization of a bacterial chromosome partitioning site. Cell 92, 675-685. doi: 10.1016/S00928674(00)81135-6

Little, J. W., Edmiston, S. H., Pacelli, L. Z., and Mount, D. W. (1980). Cleavage of the Escherichia coli lexA protein by the recA protease. Proc. Natl. Acad. Sci. U.S.A. 77, 3225-3229. doi: 10.1073/pnas.77.6.3225

Liu, Z., Mukherjee, A., and Lutkenhaus, J. (1999). Recruitment of ZipA to the division site by interaction with FtsZ. Mol. Microbiol. 31, 1853-1861. doi: 10.1046/j.1365-2958.1999.01322.x

Lutkenhaus, J. (2007). Assembly dynamics of the bacterial MinCDE system and spatial regulation of the $\mathrm{Z}$ ring. Annu. Rev. Biochem. 76, 539-562. doi: 10.1146/annurev.biochem.75.103004.142652

Lutkenhaus, J., Pichoff, S., and Du, S. (2012). Bacterial cytokinesis: from Z ring to divisome. Cytoskeleton (Hoboken) 69, 778-790. doi: 10.1002/cm.21054

Maloney, E., Madiraju, M., and Rajagopalan, M. (2009). Overproduction and localization of Mycobacterium tuberculosis ParA and ParB proteins. Tuberculosis (Edinb.) 89(Suppl. 1), S65-S69. doi: 10.1016/S1472-9792(09)70015-0

Margolin, W. (2005). FtsZ and the division of prokaryotic cells and organelles. Nat. Rev. Mol. Cell Biol. 6, 862-871. doi: 10.1038/nrm1745

Mateos-Gil, P., Márquez, I., López-Navajas, P., Jiménez, M., Vicente, M., Mingorance, J., et al. (2012). FtsZ polymers bound to lipid bilayers through ZipA form dynamic two dimensional networks. Biochim. Biophys. Acta 1818, 806-813. doi: 10.1016/j.bbamem.2011.12.012

Mazza, P., Noens, E. E., Schirner, K., Grantcharova, N., Mommaas, A. M., Koerten, H. K., et al. (2006). MreB of Streptomyces coelicolor is not essential for vegetative growth but is required for the integrity of aerial hyphae and spores. Mol. Microbiol. 60, 838-852. doi: 10.1111/j.1365-2958.2006. 05134.x

McCormick, J. R., and Losick, R. (1996). Cell division gene $f t s Q$ is required for efficient sporulation but not growth and viability in Streptomyces coelicolor A3(2). J. Bacteriol. 178, 5295-5301.
McCormick, J. R., Su, E. P., Driks, A., and Losick, R. (1994). Growth and viability of Streptomyces coelicolor mutant for the cell division gene ftsZ. Mol. Microbiol. 14, 243-254. doi: 10.1111/j.1365-2958.1994.tb01285.x

Meisner, J., Montero Llopis, P., Sham, L. T., Garner, E., Bernhardt, T. G., and Rudner, D. Z. (2013). FtsEX is required for CwlO peptidoglycan hydrolase activity during cell wall elongation in Bacillus subtilis. Mol. Microbiol. 89, 1069-1083. doi: $10.1111 / \mathrm{mmi} .12330$

Mercer, K. L., and Weiss, D. S. (2002). The Escherichia coli cell division protein FtsW is required to recruit its cognate transpeptidase, FtsI (PBP3), to the division site. J. Bacteriol. 184, 904-912. doi: 10.1128/jb.184.4.904-912.2002

Mir, M., Asong, J., Li, X., Cardot, J., Boons, G. J., and Husson, R. N. (2011). The extracytoplasmic domain of the Mycobacterium tuberculosis Ser/Thr kinase PknB binds specific muropeptides and is required for PknB localization. PLoS Pathog. 7:e1002182. doi: 10.1371/journal.ppat.1002182

Mir, M. A., Rajeswari, H. S., Veeraraghavan, U., and Ajitkumar, P. (2006). Molecular characterisation of $\mathrm{ABC}$ transporter type FtsE and FtsX proteins of Mycobacterium tuberculosis. Arch. Microbiol. 185, 147-158. doi: 10.1007/s00203005-0079-z

Mohammadi, T., Van Dam, V., Sijbrandi, R., Vernet, T., Zapun, A., Bouhss, A., et al. (2011). Identification of FtsW as a transporter of lipid-linked cell wall precursors across the membrane. EMBO J. 30, 1425-1432. doi: 10.1038/emboj.2011.61

Mohl, D. A., and Gober, J. W. (1997). Cell cycle-dependent polar localization of chromosome partitioning proteins in Caulobacter crescentus. Cell 88, 675-684. doi: 10.1016/S0092-8674(00)81910-8

Molle, V., and Kremer, L. (2010). Division and cell envelope regulation by Ser/Thr phosphorylation: Mycobacterium shows the way. Mol. Microbiol. 75, 1064-1077. doi: 10.1111/j.1365-2958.2009.07041.x

Mukherjee, A., Cao, C., and Lutkenhaus, J. (1998). Inhibition of FtsZ polymerization by SulA, an inhibitor of septation in Escherichia coli. Proc. Natl. Acad. Sci. U.S.A. 95, 2885-2890. doi: 10.1073/pnas.95.6.2885

Murray, H., and Errington, J. (2008). Dynamic control of the DNA replication initiation protein DnaA by Soj/ParA. Cell 135, 74-84. doi: 10.1016/j.cell.2008.07.044

Neumeyer, A., Hübschmann, T., Müller, S., and Frunzke, J. (2013). Monitoring of population dynamics of Corynebacterium glutamicum by multiparameter flow cytometry. Microb. Biotechnol. 6, 157-167. doi: 10.1111/1751-7915.12018

Nguyen, L., Scherr, N., Gatfield, J., Walburger, A., Pieters, J., and Thompson, C. J. (2007). Antigen 84, an effector of pleiomorphism in Mycobacterium smegmatis. J. Bacteriol. 189, 7896-7910. doi: 10.1128/JB.00726-07

Ogino, H., Teramoto, H., Inui, M., and Yukawa, H. (2008). DivS, a novel SOS-inducible cell-division suppressor in Corynebacterium glutamicum. Mol. Microbiol. 67, 597-608. doi: 10.1111/j.1365-2958.2007.06069.x

Patrick, J. E., and Kearns, D. B. (2008). MinJ (YvjD) is a topological determinant of cell division in Bacillus subtilis. Mol. Microbiol. 70, 1166-1179. doi: 10.1111/j.1365-2958.2008.06469.x

Pichoff, S., and Lutkenhaus, J. (2005). Tethering the $\mathrm{Z}$ ring to the membrane through a conserved membrane targeting sequence in FtsA. Mol. Microbiol. 55, 1722-1734. doi: 10.1111/j.1365-2958.2005.04522.x

Pichoff, S., Shen, B., Sullivan, B., and Lutkenhaus, J. (2012). FtsA mutants impaired for self-interaction bypass ZipA suggesting a model in which FtsA's selfinteraction competes with its ability to recruit downstream division proteins. Mol. Microbiol. 83, 151-167. doi: 10.1111/j.1365-2958.2011.07923.x

Plocinski, P., Arora, N., Sarva, K., Blaszczyk, E., Qin, H., Das, N., et al. (2012). Mycobacterium tuberculosis CwsA interacts with CrgA and Wag31, and the CrgA-CwsA complex is involved in peptidoglycan synthesis and cell shape determination. J. Bacteriol. 194, 6398-6409. doi: 10.1128/JB.01005-12

Plocinski, P., Ziolkiewicz, M., Kiran, M., Vadrevu, S. I., Nguyen, H. B., Hugonnet, J., et al. (2011). Characterization of CrgA, a new partner of the Mycobacterium tuberculosis peptidoglycan polymerization complexes. J. Bacteriol. 193, 3246-3256. doi: 10.1128/JB.00188-11

Priyadarshini, R., De Pedro, M. A., and Young, K. D. (2007). Role of peptidoglycan amidases in the development and morphology of the division septum in Escherichia coli. J. Bacteriol. 189, 5334-5347. doi: 10.1128/JB.00415-07

Ptacin, J. L., and Shapiro, L. (2010). Initiating bacterial mitosis: understanding the mechanism of ParA-mediated chromosome segregation. Cell Cycle 9, 4033-4034. doi: 10.4161/cc.9.20.13521

Rajagopalan, M., Maloney, E., Dziadek, J., Poplawska, M., Lofton, H., Chauhan, A., et al. (2005). Genetic evidence that mycobacterial FtsZ and FtsW proteins interact, and colocalize to the division site in Mycobacterium smegmatis. FEMS Microbiol. Lett. 250, 9-17. doi: 10.1016/j.femsle.2005.06.043 
Ramos, A., Letek, M., Campelo, A. B., Vaquera, J., Mateos, L. M., and Gil, J. A. (2005). Altered morphology produced by fts $Z$ expression in Corynebacterium glutamicum ATCC 13869. Microbiology 151, 2563-2572. doi: 10.1099/mic.0.28036-0

Raskin, D. M., and De Boer, P. A. (1999). MinDE-dependent pole-to-pole oscillation of division inhibitor MinC in Escherichia coli. J. Bacteriol. 181, 6419-6424.

Raychaudhuri, D. (1999). ZipA is a MAP-Tau homolog and is essential for structural integrity of the cytokinetic FtsZ ring during bacterial cell division. EMBO J. 18, 2372-2383. doi: 10.1093/emboj/18.9.2372

Real, G., Fay, A., Eldar, A., Pinto, S. M., Henriques, A. O., and Dworkin, J. (2008). Determinants for the subcellular localization and function of a nonessential SEDS protein. J. Bacteriol. 190, 363-376. doi: 10.1128/JB. 01482-07

Regamey, A., Harry, E. J., and Wake, R. G. (2000). Mid-cell Z ring assembly in the absence of entry into the elongation phase of the round of replication in bacteria: co-ordinating chromosome replication with cell division. Mol. Microbiol. 38, 423-434. doi: 10.1046/j.1365-2958.2000.02130.x

Reyes-Lamothe, R., Nicolas, E., and Sherratt, D. J. (2012). Chromosome replication and segregation in bacteria. Annu. Rev. Genet. 46, 121-143. doi: 10.1146/annurev-genet-110711-155421

Romberg, L., and Levin, P. A. (2003). Assembly dynamics of the bacterial cell division protein FTSZ: poised at the edge of stability. Annu. Rev. Microbiol. 57, 125-154. doi: 10.1146/annurev.micro.57.012903.074300

Santi, I., Dhar, N., Bousbaine, D., Wakamoto, Y., and McKinney, J. D. (2013). Single-cell dynamics of the chromosome replication and cell division cycles in mycobacteria. Nat. Commun. 4:2470. doi: 10.1038/ncomms 3470

Schmidt, K. L., Peterson, N. D., Kustusch, R. J., Wissel, M. C., Graham, B., Phillips, G. J., et al. (2004). A predicted ABC transporter, FtsEX, is needed for cell division in Escherichia coli. J. Bacteriol. 186, 785-793. doi: 10.1128/JB.186.3.785793.2004

Schofield, W. B., Lim, H. C., and Jacobs-Wagner, C. (2010). Cell cycle coordination and regulation of bacterial chromosome segregation dynamics by polarly localized proteins. EMBO J. 29, 3068-3081. doi: 10.1038/emboj.20 10.207

Scholefield, G., Errington, J., and Murray, H. (2012). Soj/ParA stalls DNA replication by inhibiting helix formation of the initiator protein DnaA. EMBO J. 31, 1542-1555. doi: 10.1038/emboj.2012.6

Schultz, C., Niebisch, A., Schwaiger, A., Viets, U., Metzger, S., Bramkamp, M., et al. (2009). Genetic and biochemical analysis of the serine/threonine protein kinases $\mathrm{PknA}, \mathrm{PknB}, \mathrm{PknG}$ and $\mathrm{PknL}$ of Corynebacterium glutamicum: evidence for non-essentiality and for phosphorylation of OdhI and FtsZ by multiple kinases. Mol. Microbiol. 74, 724-741. doi: 10.1111/j.1365-2958.2009. 06897.x

Shah, I. M., Laaberki, M. H., Popham, D. L., and Dworkin, J. (2008). A eukaryoticlike Ser/Thr kinase signals bacteria to exit dormancy in response to peptidoglycan fragments. Cell 135, 486-496. doi: 10.1016/j.cell.2008.08.039

Sham, L. T., Jensen, K. R., Bruce, K. E., and Winkler, M. E. (2013). Involvement of FtsE ATPase and FtsX extracellular loops 1 and 2 in FtsEX-PcsB complex function in cell division of Streptococcus pneumoniae D39. MBio 4:e00431-13. doi: 10.1128/mBio.00431-13

Sieger, B., Schubert, K., Donovan, C., and Bramkamp, M. (2013). The lipid II flippase RodA determines morphology and growth in Corynebacterium glutamicum. Mol. Microbiol. 90, 966-982. doi: 10.1111/mmi.12411

Singh, B., Nitharwal, R. G., Ramesh, M., Pettersson, B. M., Kirsebom, L. A., and Dasgupta, S. (2013). Asymmetric growth and division in Mycobacterium spp.: compensatory mechanisms for non-medial septa. Mol. Microbiol. 88, 64-76. doi: $10.1111 / \mathrm{mmi} .12169$

Slayden, R. A., and Belisle, J. T. (2009). Morphological features and signature gene response elicited by inactivation of FtsI in Mycobacterium tuberculosis. J. Antimicrob. Chemother. 63, 451-457. doi: 10.1093/jac/dkn507

Slayden, R. A., Knudson, D. L., and Belisle, J. T. (2006). Identification of cell cycle regulators in Mycobacterium tuberculosis by inhibition of septum formation and global transcriptional analysis. Microbiology 152, 1789-1797. doi: 10.1099/mic.0.28762-0

Sugimoto, S., Yamanaka, K., Nishikori, S., Miyagi, A., Ando, T., and Ogura, T. (2010). AAA+ chaperone ClpX regulates dynamics of prokaryotic cytoskeletal protein FtsZ. J. Biol. Chem. 285, 6648-6657. doi: 10.1074/jbc.M109. 080739
Sureka, K., Hossain, T., Mukherjee, P., Chatterjee, P., Datta, P., Kundu, M., et al. (2010). Novel role of phosphorylation-dependent interaction between FtsZ and FipA in mycobacterial cell division. PLOS ONE 5:e8590. doi: 10.1371/journal.pone. 0008590

Takada, H., Fukushima-Tanaka, S., Morita, M., Kasahara, Y., Watanabe, S., Chibazakura, T., et al. (2014). An essential enzyme for phospholipid synthesis associates with the Bacillus subtilis divisome. Mol. Microbiol. 91, 242-255. doi: 10.1111/mmi.12457

Thanbichler, M. (2010). Synchronization of chromosome dynamics and cell division in bacteria. Cold Spring Harb. Perspect. Biol. 2:a000331. doi: 10.1101/cshperspect.a000331

Treuner-Lange, A., Aguiluz, K., Van Der Does, C., Gómez-Santos, N., Harms, A., Schumacher, D., et al. (2013). PomZ, a ParA-like protein, regulates Z-ring formation and cell division in Myxococcus xanthus. Mol. Microbiol. 87, 235-253. doi: $10.1111 / \mathrm{mmi} .12094$

Tsuge, Y., Ogino, H., Teramoto, H., Inui, M., and Yukawa, H. (2008). Deletion of cgR_1596 and cgR_2070, encoding NlpC/P60 proteins, causes a defect in cell separation in Corynebacterium glutamicum R. J. Bacteriol. 190, 8204-8214. doi: 10.1128/JB.00752-08

Ursinus, A., Van Den Ent, F., Brechtel, S., De Pedro, M., Höltje, J. V., Löwe, J. et al. (2004). Murein (peptidoglycan) binding property of the essential cell division protein FtsN from Escherichia coli. J. Bacteriol. 186, 6728-6737. doi: 10.1128/JB.186.20.6728-6737.2004

Valbuena, N., Letek, M., Ordonez, E., Ayala, J., Daniel, R. A., Gil, J. A., et al. (2007). Characterization of HMW-PBPs from the rod-shaped actinomycete Corynebacterium glutamicum: peptidoglycan synthesis in cells lacking actinlike cytoskeletal structures. Mol. Microbiol. 66, 643-657. doi: 10.1111/j.13652958.2007.05943.x

Valbuena, N., Letek, M., Ramos, A., Ayala, J., Nakunst, D., Kalinowski, J., et al. (2006). Morphological changes and proteome response of Corynebacterium glutamicum to a partial depletion of FtsI. Microbiology 152, 2491-2503. doi: 10.1099/mic.0.28773-0

Van Baarle, S., and Bramkamp, M. (2010). The MinCDJ system in Bacillus subtilis prevents minicell formation by promoting divisome disassembly. PLoS ONE 5:e9850. doi: 10.1371/journal.pone.0009850

Van Wezel, G. P., Van Der Meulen, J., Taal, E., Koerten, H., and Kraal, B. (2000). Effects of increased and deregulated expression of cell division genes on the morphology and on antibiotic production of streptomycetes. Antonie Van Leeuwenhoek 78, 269-276. doi: 10.1023/A:10102677 08249

Vecchiarelli, A. G., Han, Y. W., Tan, X., Mizuuchi, M., Ghirlando, R., Biertumpfel, C., et al. (2010). ATP control of dynamic P1 ParA-DNA interactions: a key role for the nucleoid in plasmid partition. Mol. Microbiol. 78, 78-91. doi: 10.1111/j.1365-2958.2010.07314.x

Wang, X., Montero Llopis, P., and Rudner, D. Z. (2013). Organization and segregation of bacterial chromosomes. Nat. Rev. Genet. 14, 191-203. doi: $10.1038 / \operatorname{nrg} 3375$

Weart, R. B., Lee, A. H., Chien, A. C., Haeusser, D. P., Hill, N. S., and Levin, P. A. (2007). A metabolic sensor governing cell size in bacteria. Cell 130, 335-347. doi: 10.1016/j.cell.2007.05.043

Weart, R. B., and Levin, P. A. (2003). Growth rate-dependent regulation of medial FtsZ ring formation. J. Bacteriol. 185, 2826-2834. doi: 10.1128/JB.185.9.28262834.2003

Weart, R. B., Nakano, S., Lane, B. E., Zuber, P., and Levin, P. A. (2005). The ClpX chaperone modulates assembly of the tubulin-like protein FtsZ. Mol. Microbiol. 57, 238-249. doi: 10.1111/j.1365-2958.2005.04673.x

Webb, C. D., Graumann, P. L., Kahana, J. A., Teleman, A. A., Silver, P. A., and Losick, R. (1998). Use of time-lapse microscopy to visualize rapid movement of the replication origin region of the chromosome during the cell cycle in Bacillus subtilis. Mol. Microbiol. 28, 883-892. doi: 10.1046/j.1365-2958.1998. 00808.x

Weiss, D. S., Chen, J. C., Ghigo, J. M., Boyd, D., and Beckwith, J. (1999). Localization of FtsI (PBP3) to the septal ring requires its membrane anchor, the $\mathrm{Z}$ ring, FtsA, FtsQ, and FtsL. J. Bacteriol. 181, 508-520.

Wieschalka, S., Blombach, B., Bott, M., and Eikmanns, B. J. (2013). Bio-based production of organic acids with Corynebacterium glutamicum. Microb. Biotechnol. 6, 87-102. doi: 10.1111/1751-7915.12013

Willemse, J., Borst, J. W., De Waal, E., Bisseling, T., and Van Wezel, G. P. (2011). Positive control of cell division: FtsZ is recruited by SsgB 
during sporulation of Streptomyces. Genes Dev. 25, 89-99. doi: 10.1101/gad. 600211

Wu, L. J., and Errington, J. (1994). Bacillus subtilis SpoIIIE protein required for DNA segregation during asymmetric cell division. Science 264, 572-575. doi: $10.1126 /$ science. 8160014

Wu, L. J., and Errington, J. (2004). Coordination of cell division and chromosome segregation by a nucleoid occlusion protein in Bacillus subtilis. Cell 117, 915-925. doi: 10.1016/j.cell.2004.06.002

Yang, D. C., Peters, N. T., Parzych, K. R., Uehara, T., Markovski, M., and Bernhardt, T. G. (2011). An ATP-binding cassette transporter-like complex governs cell-wall hydrolysis at the bacterial cytokinetic ring. Proc. Natl. Acad. Sci. U.S.A. 108, E1052-E1060. doi: 10.1073/pnas.11077 80108

Yi, Q. M., Rockenbach, S., Ward, J. E., Jr., and Lutkenhaus, J. (1985). Structure and expression of the cell division genes ftsQ, ftsA and ftsZ. J. Mol. Biol. 184, 399-412. doi: 10.1016/0022-2836(85)90290-6
Conflict of Interest Statement: The authors declare that the research was conducted in the absence of any commercial or financial relationships that could be construed as a potential conflict of interest.

Received: 30 November 2013; accepted: 14 March 2014; published online: 10 April 2014.

Citation: Donovan C and Bramkamp M (2014) Cell division in Corynebacterineae. Front. Microbiol. 5:132. doi: 10.3389/fmicb.2014.00132

This article was submitted to Microbial Physiology and Metabolism, a section of the journal Frontiers in Microbiology.

Copyright (C) 2014 Donovan and Bramkamp. This is an open-access article distributed under the terms of the Creative Commons Attribution License (CC BY). The use, distribution or reproduction in other forums is permitted, provided the original author(s) or licensor are credited and that the original publication in this journal is cited, in accordance with accepted academic practice. No use, distribution or reproduction is permitted which does not comply with these terms. 